\title{
Drought characterization over India under projected climate scenario
}

Deepak Singh Bisht ${ }^{1}$, Venkataramana Sridhar ${ }^{2}$, Ashok Mishra ${ }^{1}$, Chandranath Chatterjee ${ }^{1}$, Narendra Singh Raghuwanshi, ${ }^{1,3}$

(1) Department of Agricultural and Food Engineering, Indian Institute of Technology Kharagpur, Kharagpur, India

(2) Department of Biological Systems Engineering, Virginia Polytechnic Institute and State University, Blacksburg, VA, USA

(3) Maulana Azad National Institute of Technology, Bhopal, India

\section{Abstract}

The study evaluates the drought characteristics in India over projected climatic scenarios in different time frames i.e., near-future (2010-2039), mid-future (2040-2069), and far-future (2070-2099) in comparison with reference period (1976-2005). Standardized Precipitation Evapotranspiration Index (SPEI), a multiscalar drought index was used owing to its robustness in capturing drought conditions while accounting the temperature. Gridded rainfall and temperature data provided by India Meteorological Department (IMD) was used to perform bias correction of 9 Global Climate Models (GCMs) from Coupled Model Intercomparison Project Phase 5 (CMIP5) project. Quantile mapping was used to correct the daily rainfall data at seasonal scale whereas daily temperature data was corrected at monthly scale. Multi-Model Ensemble (MME) was prepared for different homogeneous monsoon regions of India, namely Hilly Regions (HR), Central Northeast (CNE), Northeast (NE), Northwest (NW), West Central (WC), and Peninsula (PS). Taylor diagram statistics were used for the preparation of MME. The regional climate cycle obtained from MME was found to be in good agreement with observed cycle derived from IMD data. The Mann-Kendal trend test was employed to detect the trend in drought severity and magnitude whereas $L$-moments based frequency analysis was used to assess the magnitude of extreme drought severity under different time frames. The study reveals an increasing trend in drought severity, duration, occurrences, and the average length of drought under warming climate scenarios. Furthermore, the area under 'above moderate drought' (i.e., severe and extreme drought combined) condition was also found to be increasing in projected climate.

This article has been accepted for publication and undergone full peer review but has not been through the copyediting, typesetting, pagination and proofreading process, which may lead to differences between this version and the Version of Record. Please cite this article as doi: $10.1002 /$ joc. 5922 
Keywords: Drought, SPEI, MME, Projected climate, India

\section{Introduction}

Expecting abnormal weather conditions in the form of intense storm, prolonged heat wave spells, pluvial flooding, cloudburst, chilling weather, continuous drought situations have become a norm owing to the exacerbated climatic conditions across the globe. Though each of the aforementioned problems has its implication on human lives and economy of a nation, drought is undeniably the most concerning problem that adversely affects the food security and livelihood of farmers by hampering crop production, and economic growth of a country. For instance, in India, farm revenues are likely to decrease by $20-25 \%$ in the medium term due to the unfavorable climatic condition causing a dent into country's economy as agriculture sector accounts for $16 \%$ of Gross Domestic Product (Ministry of Finance- India, 2018). Prolonged drought causes poor crop production resulting in inflation which in turn leads to sociopolitical unrest and slower economic growth. Compared to any other natural hazard, drought affects number of people, therefore it's essential to develop an understanding of drought characteristics (Kang and Sridhar, 2018, 2017; Mishra and Singh, 2011).

Droughts can be analyzed on short-term as well as on a long-term basis. Short-term drought forecasts can aid into crop management by releasing appropriate advisory regarding suitable crops, allocating drought relief funds to help farmers and reallocations of water resources among states. Future drought projections in long-term are of vital importance in terms of policy-making to combat water crisis in a longer time frame by the means of improved infrastructure to manage water resources, groundwater recharge projects, rainwater harvesting schemes etc. Numerous studies across the globe reported the possible increase in various drought characteristic i.e., severity, duration, and intensity. Trenberth et al. (2013) suggested the likelihood of more extensive natural droughts with a possibility of quick onset, higher intensity, and longer duration. In another study covering a time span of 1950-2008, Dai (2011) reported the increase in global percentage dry area with a rate of $1.74 \%$ per decade. In the context of future global drought, Burke and Brown (2008) reported a higher increase in the areal spread of more severe drought than less severe drought with an overall increase in the area affected under drought on a global scale. According to IPCC (2012) at a medium level of confidence, drought is likely to increase in

This article is protected by copyright. All rights reserved. 
future where some region may experience more intense drought. Several regional studies performed on various parts of the world ( Lee et al., 2018; Spinoni et al., 2018; Thilakarathne and Sridhar, 2017; Chen and Sun, 2017; Nam et al., 2015; Yu et al., 2014; Wang et al., 2011) invariably reported the increase in the drought events in changing climatic conditions. During 1950-2006, Wang et al. (2011) observed that soil moisture droughts became longer, more severe and more frequent for central and northeastern China. An analysis of drought using Standardized Precipitation Evapotranspiration Index (SPEI) by Yu et al. (2014) for period 1951-2010 over China revealed that above moderate droughts have become more serious. Furthermore, SPEI derived using Coupled Model Intercomparison Project Phase 5 (CMIP5) family of climate model infers aggravated drought conditions under projected scenarios (Chen and Sun, 2017) in China. Nam et al. (2015) analyzed the future drought characteristics over South Korea using SPEI, Standardized Precipitation Index (SPI), and Self-Calibrating Palmer Drought Severity Index (SC-PDSI); they reported an increasing drought severity and magnitude in the region. Majority of Korean Peninsula is also found to experience significant drought risk under various climatic scenarios (Lee et al., 2018). Spinoni et al. (2018) analyzed the drought over Europe under RCP 4.5 and RCP 8.5 scenario using SPI, SPEI, and Reconnaissance Drought Indicator (RDI). Under both the scenarios, frequency of drought was found to be increasing in Europe during spring and summer. More severe and intense droughts were found to be prevalent in Lower Mekong Basin in projected climatic scenario (Thilakarathne and Sridhar, 2017).

Increased risk of drought due to increased prolonged dry spells, total dry days, and decreased light precipitation days over India can be attributed to global warming (Mishra and Liu, 2014). Characterization of droughts in India have been the focus of many studies (Sharma and Mujumdar, 2017; Zhang et al., 2017; Thomas et al., 2015; Mallya et al., 2016; Mishra et al., 2014; Ojha et al., 2013; Naresh Kumar et al., 2012; Mishra and Singh, 2009). Zhang et al. (2017) reconstructed the drought during 1981-2013 in major wheat growing regions in India to demonstrate its implication on wheat production. They also reported the increased severity of vegetation and meteorological droughts in certain sub-regions. Droughts in India are further found to have an increasing trend in their severity and frequency during 1972-2004 (Mallya et $a l ., 2016)$ with increasing areal extent concurrently affected by droughts and heatwaves across the country (Sharma and Mujumdar, 2017). Naresh Kumar et al. (2012) reported an increase in the spatial extent of area under moderate drought frequency in India during the recent decade. In

This article is protected by copyright. All rights reserved. 
regional studies, increased frequency and severity of drought was reported for Bundelkhand region over last decade (Thomas et al., 2015) in the central India whereas in Kangsabati river basin of eastern India more severe drought with increased areal extent was projected in the first half of $21^{\text {st }}$ century (Mishra and Singh, 2009). Employing SPI, estimated using bias-corrected monthly time series of 17 Global Climate Models (GCMs) Ojha et al. (2013) found the likelihood of a rise in the number of drought events in west central, central northeast, and peninsular India. Utilizing soil moisture-based drought indices Mishra et al. (2014) predicted an increase in the areal extent and frequency of severe, extreme, and exceptional droughts in the majority of crop-growing seasons during 2010-2039 and 2040-2069, in India. Unlike SPI, SPEI, or RDI, drought characterization using soil moisture-based indices require many variables such as rainfall, maximum and minimum temperature, wind speed, land use land cover, soil type information, topographic information, values of numerous parameters related to vegetation and soil class to setup hydrological models and soil-moisture measurement, streamflow observations for calibration and validation (Mishra et al., 2014). Such exercises are often computationally expensive, time consuming, and require model expertise.

Afore-discussed studies in Indian context, except few, utilized the SPI for drought characterization under a projected climate that only account for the precipitation (Mckee et al., 1993). One of the major critiques of SPI is that it doesn't account for the effect of temperature which is imperative in the view of the warming climate (Liu et al., 2016). Increased temperature leads to higher water demand, therefore for projected climate it is important to use drought indices which also account for the temperature in its formulation such as SC-PDSI or SPEI (Vicente-Serrano et al., 2010). However, owing to the simplicity of SPEI, multiscalar properties, and lower data requirement Vicente-Serrano et al. (2010) suggested to use SPEI. While analyzing projected climatic scenarios instead of utilizing a stand-alone GCM output using an ensemble of GCMs output gives many reliable estimates as it encompasses the range of model induced uncertainties (Weigel et al., 2010). The present study aims to analyze the medium term drought (SPEI-3 or three monthly SPEI) characteristics (duration, severity, areal extent) during projected climate scenarios (RCP 4.5 and RCP 8.5) vis-à-vis historical period using multi-model ensemble (MME) of bias-corrected data from the CMIP5 family of GCMs. To peek into the future scenarios an unconventional approach was adopted to have region-wise MME of rainfall

This article is protected by copyright. All rights reserved. 
and temperature by selecting a different set of models instead of employing the same set of models across the entire landmass.

In the light of discussion made above, the objectives of this study were to (1) perform biascorrection of GCM rainfall and temperature under projected climate scenarios (i.e., RCP 4.5 and RCP 8.5) and to develop a Multi-Model Ensemble (MME) dataset that best captures the regional climatic seasonality (2) estimate temperature based drought indices i.e., SPEI-3 across the spatial and temporal scale to analyze the pattern of drought severity and duration, and (3) study the possible trend in areal spread of drought under warming scenarios over mainland India. The paper is organized as follows. Section 2 describes the methodology, sections 3 deals with results and discussions. Conclusions borne out from the study are outlined in section 4.

\section{Methodology}

\subsection{Data used}

Rainfall and temperature records are required to analyze drought characteristics using SPEI. In the present study, high resolution gridded observed rainfall data at $0.25^{\circ}$ spatial resolution (Pai et $a l ., 2014)$ and gridded temperature data at $1^{\circ}$ spatial resolution were procured from India Meteorological Department (IMD), Pune. IMD rainfall has been widely used in a variety of studies (Bisht et al., 2018,2017; Smitha et al., 2018; Beria et al., 2017; Sharma and Mujumdar, 2017; Meher et al., 2017; Deshpande et al., 2016; Mishra et al., 2014). IMD rainfall data was developed utilizing the daily rainfall observations with varying periods of records of 6955 stations after quality control. Owing to an extensive number of rain gage stations used in the preparation of the dataset and high spatial resolution, it captures the rainfall climatology, spatial distribution, and orographic effects with reasonable accuracy; readers are encouraged to refer Pai et al. (2014) for further details. IMD gridded temperature data was developed using quality control records of 395 stations and has been used in a range of studies published in the recent past (Paul et al., 2018; Smitha et al., 2018; Beria et al., 2017; Chakraborty et al., 2017; Sharma and Mujumdar, 2017; Deshpande et al., 2016; Kumar et al., 2013). To ensure the consistency in spatial resolution of the dataset, gridded temperature record was remapped from $1^{\circ}$ to $0.25^{\circ}$ spatial resolution using bilinear interpolation following Sharma and Mujumdar (2017).

To analyze the future drought characteristics, projected climate data from the CMIP5 family of models were downloaded from Earth System Grid Federation web portal (https://esgfnode.llnl.gov/projects/esgf-llnl/) as listed in Table 1. Owing to the computational limitation, in

This article is protected by copyright. All rights reserved. 
the present study we have used historical, RCP 4.5, and RCP 8.5 scenarios from the first ensemble member (r1i1p1) of each model. To ensure the spatial scale consistency across the models we remapped the dataset available at various resolution to IMD rainfall resolution using Climate Data Operators (CDO) package (available at: http://www.mpimet.mpg.de/cdo) that uses bilinear interpolation technique following Das et al. (2012) and Akhter et al. (2017).

\subsection{Bias-correction of projected rainfall and temperature}

An imprecise assumption in model physics and incomplete knowledge of geophysical process result into differences in observed and simulated climatic conditions. This difference is termed as bias in the model output. Therefore, it is imperative to correct the model outputs using appropriate techniques to best utilize the GCM projection under different climatic scenarios (Dhage et al., 2016). Downscaled climatic scenario over the globe for an array of GCMs are available at finer resolution that can be obtained from NASA Earth Exchange Global Daily Downscaled Projections (NEX-GDDP). However, NEX-GDDP employed Global Meteorological Forcing Dataset (GMFD) as observational dataset instead of IMD records. Therefore, an attempt was made to utilize IMD dataset to bias-correct the climatic projections. In the present study, quantile mapping technique (Li et al., 2010) was used to perform biascorrection on GCM simulated temperature and rainfall data. Daily time series of rainfall data were aggregated on seasonal scale i.e., JJAS - ONDJF - MAM which also corresponds to Monsoon, Post-monsoon and Pre-monsoon season in India, respectively. In terms of crop growing season, these can be aptly related with Rabi, Kharif, and Zaid, respectively. Biascorrection was performed using seasonal time series of daily rainfall data from observed (henceforth IMD) and GCM data using gamma distribution. Bias-correction for daily temperature data was performed on a monthly scale using Gaussian distribution. In case of temperature, bias-correction was performed for maximum temperature (Tmax) and diurnal temperature range (DTR), thereafter minimum temperature (Tmin) was computed by deducting DTR from Tmax as recommended by Thrasher et al. (2012). Quantile mapping for rainfall and temperature data for historical and projected scenarios were performed as per the methodology discussed in Salvi et al. (2013) and Dhage et al. (2016). Historical time series of uncorrected GCM data during 1951-2005 was divided into 1951-1975 i.e., 25 years and 1976-2005 i.e., 30 years for testing and training of bias-correction technique, respectively whereas climatic projection form RCP 4.5 and RCP 8.5 scenarios were divided into three timeframes i.e., 2010-

This article is protected by copyright. All rights reserved. 
2039 (near future), 2040-2069 (mid future), 2070-2099 (far future). It is worth noting that recent climatic window i.e., 1976-2005 was employed for training period as it closely represents the current climate compared to testing period i.e., 1951-1975.

To prepare MME dataset, different homogenous monsoon regions of India as defined by Indian Institute of Tropical Meteorology (IITM), Pune were considered. These regions (Fig. 1) are classified as Hilly Regions (HR), Central Northeast (CNE), Northeast (NE), Northwest (NW), West Central (WC), and Peninsula (PS). Preparation and evaluation of MME dataset for rainfall and temperature are discussed in section 3.1.1 and 3.1.2.

\subsection{Drought characteristics}

SPEI is reported to capture effect of temperature in drought development with reasonable accuracy compared to SPI, a precipitation based index that does not account the role of temperature in drought development. Liu et al. (2016) and Vicente-Serrano et al. (2010) recommended to use SPEI under warming climate scenario. Of late SPEI has gained popularity in analyzing drought characteristics under projected scenarios, and numerous studies can be referred in Törnros and Menzel (2014), Wang et al. (2014), Rhee et al. (2016), Smirnov et al. (2016), Wu et al. (2016), Chen and Sun (2017), Feng et al. (2017), Dibike et al. (2017), Bonsal et al. (2017), Oguntunde et al. (2017), Khan et al. (2017), Gao et al. (2017), Huang et al. (2018), Zhang et al. (2018) and Spinoni et al. (2018). In the present study, drought characteristic was analyzed using SPEI-3. It represents the short and medium term moisture deficit/excess conditions computed over a 3-month period and primarily important to highlight the available moisture condition in the context of agriculture. SPEI estimation requires monthly water deficit (MWD) i.e., the difference of monthly precipitation $(\mathrm{P})$ and monthly potential evapotranspiration (PET). Hargreaves (Dibike et al., 2017; Oguntunde et al., 2017; Rhee et al., 2016; Spinoni et al., 2018), Thornthwaite (Bonsal et al., 2017; Chen and Sun, 2017; Feng et al., 2017; Khan et al., 2017; Smirnov et al., 2016; Törnros and Menzel, 2014; Wu et al., 2016), and Penman-Monteith (Feng et al., 2017; Gao et al., 2017; Huang et al., 2018; Wang et al., 2014; Zhang et al., 2018) are the three most commonly used PET estimation methods employed in SPEI based drought studies under projected scenarios. Penman-Monteith method is the best reported method and data intensive, Hargreaves method utilizes daily maximum and minimum temperature whereas Thonthwaite requires monthly mean temperature. Due to data limitation Penman-Monteith method could not be employed and since, Hargreaves method is reported to have better

This article is protected by copyright. All rights reserved. 
performance over Thornthwaite method (Bandyopadhyay et al., 2012) we chose Hargreaves method (Allen et al., 1998) for PET estimation. Here it is worth noting that PET inclusion in drought index serves to obtain a relative temporal estimation, therefore PET estimation methods itself are not crucial (Vicente-Serrano et al., 2010). In the present study, an R-package (available at: https://cran.r-project.org/web/packages/SPEI/) was used for SPEI computation. To understand the mathematical formulation of SPEI, readers are encouraged to refer Vicente-Serrano et al. (2010).

To compare drought development across the time frames i.e., reference period (1976-2005), near-future (2010-2039), mid-future (2040-2069), and far-future (2070-2099), transformation obtained for SPEI computation in reference period was used for SPEI computation in the projected scenario as demonstrated by Stagge et al. (2015). Owing to the similar nature of computation criteria, drought classification for SPEI is same as used for the SPI hence, can be adopted from Hayes et al. (1999). Drought severity classification criteria are shown in Table 2.

\subsubsection{Drought severity, duration, and areal spread}

To analyze drought characteristics over India; severity, duration, and area under drought were studied. Drought severity and durations were estimated using 'run theory' given by Yevjevich (1967) and shown in Fig. 2. Thilakarathne and Sridhar (2017) and Mishra and Desai (2005) also used 'run theory' to analyze drought characteristics using SPI under projected and retrospective periods, respectively. Compared to moderate droughts, severe and extreme droughts are much detrimental to crop growth, therefore, severe and extreme droughts were combined as above moderate drought in the analysis. Besides the change in average length of droughts and number of drought occurrences in warming climate scenarios were studied vis-à-vis reference period. The average length of drought is the ratio of the total number of drought months experienced during a time frame and number of drought incidences, where drought incidences are the count of occurrences of consecutive drought months. To study the areal extent of drought, fraction of area under drought were computed by identified drought affected grids (for moderate and above moderate drought, separately) across all the months of a time frame. Thereafter, for each year highest drought spread area fraction was extracted to study the trend in the area under drought.

\subsubsection{Frequency analysis}

In the present study, frequency analysis using $L$-moments approach was employed to estimate the drought severity and duration of various return periods. $L$-moments approach to estimate

This article is protected by copyright. All rights reserved. 
parameters for distribution is reported to be superior to other methods (Kumar and Chatterjee, 2011; Hosking and Wallis, 1997). Five 3-parameter distributions, namely, generalized extreme value (GEV), generalized logistic (GLO), generalized normal (GNO), Pearson type-III (PE3), generalized pareto (GPA), and one 5-parameter distribution Wakeby (WAK) were employed. $L$ moments ratio diagrams were often used in conjunction with Z-dist statistics to identify the best fit distribution for a given sample (Bisht et al., 2016; Samantaray et al., 2015; Jena et al., 2014; Kumar and Chatterjee, 2005, 2011). However, a sample can be fitted into more than one distribution in many cases, and in such cases Z-dist statistics is used to identify the best-fit distribution. The best fit for a sample is identified if |Z-dist| statistic is sufficiently close to 0 and less than 1.64 (Kumar and Chatterjee, 2011). For cases, where none of the 3-parameters distribution show $\mid Z$-dist $\mid<1.64$, a 5-parameter distribution, Wakeby, is employed for the robustness of analysis (Samantaray et al., 2015; Hosking and Wallis, 1997). Owing to a large number of grids in the present study, only Z-dist statistics were used. To have a better understanding of mathematical expression and advantages of $L$-moments based frequency analysis, readers may refer to Kumar and Chatterjee (2011).

\subsubsection{Trend analysis}

To identify the trend in the area under drought (AUD) under different time frames, two nonparametric tests, namely, Mann-Kendal (MK)/ modified Mann-Kendal (MMK) test (Rao et al., 2003; Hamed and Rao, 1998) and Theil-Sen's slope (TSS) (Sen, 1968; Theil, 1950) were used.

The accuracy of MK test deteriorates due to the presence of autocorrelation in the time series, therefore, for the auto-correlated data MMK test was used. MK/MMK and TSS were widely applied in numerous studies due to their robustness in identifying trend in the time series (Bisht et al., 2017; Dhage et al., 2016; Liu et al., 2016; Osuch et al., 2016; Jena et al., 2014; Mishra et al., 2014; Naresh Kumar et al., 2012; Bandyopadhyay et al., 2009). Gao et al. (2017), Khan et al. (2017), Wu et al. (2016), and Zhang et al. (2018) used Mann-Kendall test to analyze the trend in drought characteristics under projected climatic scenarios. Descriptions of these statistical tests can be found in Bisht et al. (2017) and therefore, not elaborated in this article.

\section{Results and Discussion}

\subsection{Development of MME of bias-corrected rainfall and temperature}

\subsubsection{Development of MME of bias-corrected rainfall}

This article is protected by copyright. All rights reserved. 
Quantile mapping based bias-correction technique as illustrated in Dhage et al. (2016) and Salvi et al. (2013) was used for bias-correction of daily rainfall data. Bias-correction was performed on seasonal scale instead of monthly scale as during the exercise few of the IMD grids were identified with zero rainfall records throughout the length of training period primarily during non-monsoon months in arid regions. Such grids cannot be utilized in distribution mapping for climate data, however, on a seasonal scale where daily rainfall records were pooled from multiple months such problems do not arise. However, frequency correction of rainfall days for GCMs was performed on monthly scale using the IMD data of training period (1976-2005). Suitability of bias-corrected dataset of each of the participating GCMs was evaluated comparing its pattern with IMD data in terms of variation i.e., standard deviation (SD), correlation coefficient (CC), and root-mean-square difference (RMSD) utilizing Taylor diagram (Taylor, 2001).

To ensure bias-corrected dataset captures the seasonality, instead of assessing the seasonality on all India scale, mean monthly bias-corrected rainfall data from different GCMs were compared against IMD data for individual homogeneous monsoon regions of India classified by IITM. It is worth noting that hilly regions were not considered in the preparation of aforementioned classification, however, are taken as a single unit owing to the similar physiographic characteristics. Variability in rainfall regime across the homogeneous regions including hilly regions as compared to all India scale variability is evident from Fig. 3 for annual as well as seasonal (i.e., JJAS, MAM, ONDJF) scales. Northeast region shows the highest amount of rainfall compared to all India scale and all other regions for annual, and seasonal cases except for the ONDJF in which peninsular India shows highest rainfall and variability. Such variability in rainfall across the country makes it imperative to evaluate the bias-corrected rainfall against region-specific seasonality for better representation. Therefore, in the present study, accuracy of bias-corrected rainfall were assessed for different homogeneous regions (Fig. 1) to better capture the seasonality instead of all India scale using Taylor diagram (Fig. 4). Models with higher accuracy vis-à-vis IMD data during both training (1976-2005) and testing (1951-1975) period were deemed fit for preparation of MME. Taylor diagram statistics obtained for bias-corrected data of GCMs considered in the study are tabulated in Table 3. While selecting the models for MME preparation, attempt was made to ensure selection of maximum number of models without compromising the MME accuracy and performance in capturing the regional seasonality. Taylor

This article is protected by copyright. All rights reserved. 
diagrams in Fig. 4 and Fig. 5 show the statistical comparison of individual models with IMD. A model performance was taken as satisfactory if following 3 conditions met; (1) the difference in standard deviation of model and IMD is minimal i.e., it lies closer to the solid line passing through IMD inferring that pattern variation of the model matches with IMD, (2) higher correlation coefficient, and (3) minimal root-mean-square difference. Following this model combinations for MME were carefully identified for respective homogeneous region shown in Table 4.

In present study, equal weights were assigned for ensemble mean. MME derived regional seasonal cycle of precipitation was found to be in good agreement with IMD. Ability to resolve rainfall seasonality of MME across different regions were verified using color matrix and error plots of mean monthly rainfall of individual GCMs and MME for training and testing period as shown in Fig. 6 and Fig. 7, respectively. It is evident from the visual inspection that MME performs better than individual models and in good agreement with IMD during training as well as testing period. This can be ascertained from the color gradient for the error plots and color matrix of mean monthly rainfall. Besides, MME mimics the seasonal cycle of regional monthly rainfall with reasonable accuracy for both training and testing periods; except for peninsular India that showed marginal deviation from the IMD. Interestingly, IPSL-CM5A-LR and IPSLCM5A-MR showed the highest departure from IMD across all the regions compared to other models as shown in error plots (darker shades show higher deviation from the IMD) as well as in Taylor diagrams for training and testing period therefore are not considered for including in MME development.

Besides assessing the MME skill in resolving the rainfall climatology for homogeneous regions, a qualitative evaluation by means of Hovmoller diagram (Fig. 8) was also employed to assess the ability of MME to resolve seasonality across the latitudes. MME captures the temporal evolution of monthly rainfall with reasonable accuracy during training and testing period across the latitudes and found to be in good agreement with IMD rainfall pattern except for some of the northernmost latitudes that mostly represent the mountain range of the Himalayas and are very few in numbers. Across all the latitudes, the majority of the rainfall concentrated in monsoon season i.e., JJAS (southwest monsoon) are captured well by the MME. Southernmost latitudes approximately up to $14^{\circ} \mathrm{N}$ from peninsular India receive high rainfall during October and November months due to northeast monsoon are also captured with reasonable accuracy by

This article is protected by copyright. All rights reserved. 
MME for training and testing period. As per the afore-discussed exercise, the ability of MME in resolving the monthly rainfall pattern across the latitudes and different homogeneous regions is found to be satisfactory for further analysis.

\subsubsection{Development of MME of bias-corrected temperature}

Temperature data was bias-corrected using the same technique as employed in the biascorrection of rainfall. However, instead of seasonal time series, monthly time series of daily temperature data was used i.e., uncorrected GCM temperatures of all January months were corrected using IMD temperature of January months. Separate correction of Tmax and Tmin often results in unrealistic DTR where Tmin exceeds Tmax in corrected data. Therefore, firstly Tmax and DTR were corrected and subsequently corrected Tmin was computed from Tmax and DTR as recommended in Thrasher et al. (2012). Identified GCMs used in MME of rainfall (Table 4) were selected for MME of temperature for respective homogeneous regions. Here, it is worth mentioning that bias-corrected temperature resolves the seasonality better than the biascorrected rainfall data in general. Hence, selecting an identified set of GCMs for MME of rainfall can be recommended for preparation of MME of temperature as well. This further ensures the rainfall and temperature comes from the same GCM for respective MME. Corrected Tmax and Tmin for training period along with the projected scenarios are shown in Fig. 9 and Fig. 10. The higher increase in temperature can be clearly seen in RCP 8.5 compared to RCP 4.5 scenario. Hovmoller diagrams for MME Tmax and MME Tmin during training and testing period are included in the supplementary material (Fig. S1, Fig. S2).

\subsection{Drought characterization}

The 3-month SPEI that provides a comparison of the water deficit/excess over a specific 3-month period for the study duration, is used for analyzing the drought characteristics. Owing to the fact that majority of the crops have a growing period of 3-4 months, SPEI-3 is more relatable in investigating effects of drought on vegetation. The focus of this study is to analyze drought patterns in projected scenario using bias-corrected MME dataset rather than retrospective investigation. Retrospective drought characteristics over India have been addressed by Sharma and Mujumdar (2017), Mallya et al. (2016) and Naresh Kumar et al. (2012) in detail, hence not taken up in the present study. To study drought behaviors in warming scenario drought severity, duration, and occurrences were estimated during 1976-2005 i.e., reference period and compared with the respective indices for near-future (2010-2039), mid-future (2040-2069), and far-future

This article is protected by copyright. All rights reserved. 
(2070-2099) under projected RCP 4.5 and RCP 8.5 scenarios. Besides, frequency analysis was performed to demonstrate the change in 25 year return period of severity and duration using $L$ moments based frequency analysis approach. To study the areal spread of drought, total area affected by drought was estimated for each year. For this purpose 'moderate droughts' and 'above moderate droughts' (i.e., drought either characterized as severe drought or extreme drought) indicated by $-0.1<=$ SPEI $>-1.5$ and SPEI $<=-1.5$ were considered. Drought characteristics in terms of severity, areal spread, duration, and occurrences are discussed in following section.

\subsubsection{Drought severity and areal spread}

Trend analysis using MMK test was performed to investigate the pattern of drought severity and areal spread. While analyzing the 30-year time frames majority of the grids showed a nonsignificant trend in drought severity magnitude computed using 'run theory' as shown in Fig. 2 on annual basis. However, on long-term basis i.e., for entire projected time period (2010-2099) increase in the magnitude of drought severity was found to be significant at $5 \%$ level of significance across the country under both the RCP 4.5 and RCP 8.5 scenarios (Fig. 11). The reason can be attributed to the substantial increase in the drought severity magnitude in far future in comparison to near future. This also infers that far-future and mid-future may show increased drought severity compared to mid-future and near-future, respectively. To validate this, frequency analysis of drought severity was performed for historical as well as near-future, midfuture, and far-future time frames using $L$-moments based approach.

As discussed earlier best fit distributions were identified (Fig. 12) from the five 3-parameter distributions, namely generalized extreme value (GEV), generalized logistic (GLO), generalized normal (GNO), Pearson type-III (PE3), generalized Pareto (GPA), and one 5-parameter distribution Wakeby (WAK) for each grid. Frequency analysis of drought severity was performed for each grid computing the growth factors using the parameters of corresponding best fit distributions shown in Fig. 12. A 25-year return period of drought severity was computed over each 30 year timeframe. The magnitude of drought severity was found to be increasing for 25 year return period in comparison to reference period for all the time frames under RCP 4.5 and RCP 8.5 scenario. This increase was found to be maximum for mid-future and far-future (Fig. 13) in the northwest, west-central, and central northeast India. Higher magnitude of 25 year return period drought severity in different time frames under projected scenarios infers the

This article is protected by copyright. All rights reserved. 
increased severity that may not have a significant increasing trend (Fig. 11) but nevertheless has a higher magnitude than preceding time frames.

To analyze the drought spread MMK test was performed on each time frame i.e., near-future, mid-future, and far-future; as well as on long-term basis i.e., entire projected time length of 2010-2099. The area subjected to moderate droughts was found to be decreasing for both the scenarios i.e., RCP 4.5 and RCP 8.5 except for far-future which shows a non-significant increasing trend (Table 5; Fig. 14). In the long-term, area under moderate drought is found to be decreasing significantly at 5\% significance level under RCP 4.5 and RCP 8.5 scenarios (Fig. 14). Contrary to moderate droughts an increasing trend is found to be prevalent in the areal spread of above moderate drought under both the scenarios, however, the trends were significant for longterm scale i.e., 2010-2099. For all the time frames studied, moderate drought is found to be replaced by above moderate drought conditions that may pose an alarming state for Indian agriculture and water resource managers. Though the increasing trends lack the statistical significance in a shorter time frame for above moderate droughts except for the mid-future under RCP 4.5 scenario; increase in the areal spread in mid-future, and far-future compared to nearfuture, and mid-future, respectively is evident from Fig. 14 for both the scenarios. Long-term decreasing and increasing significant trends in the areal spread of moderate and above moderate droughts can be attributed to the change in the areal spread of droughts, though non-significant, in smaller timeframes.

\subsubsection{Drought duration and occurrences}

Trend analysis was performed on the durations of SPEI-3 drought months. For this, the time series were prepared considering the maximum duration of droughts length in a single run over each year using 'run theory' as shown in Fig. 2. As shown for severity trends in Fig. 11, in long run, duration of drought length was found to increase significantly at 5\% significance level over the majority of the country (Fig. 15). However, very few number of grids showed statistically significant trends on smaller time frames. On a long-term basis Indo-Gangetic plains, part of central India, north-western India and Upper Peninsular India are found to be more severely affected under projected climatic scenarios. As discussed for the drought severity case in preceding section, a strong trend in drought durations (in months) over the long run can be attributed to increase in individual time frames. This can be further validated from Fig. 16 which shows an increase in the average length of drought in far-future and mid-future compared to mid-

This article is protected by copyright. All rights reserved. 
future and near-future, respectively. The long-term increasing trend in drought duration (Fig. 15) and increased average length of drought (Fig. 16) infers the likelihood of long runs of SPEI-3 drought months under warming scenarios. The situation can be further aggravated by increasing drought severity as discussed in section 3.2.1. Besides drought severity, duration, and length; frequency of drought events were analyzed by the means of drought occurrences across the time frames. Drought occurrences were computed in each time frame by analyzing the counts of consecutive drought months. Interestingly, in comparison to the reference period, future time frames under projected scenarios showed increased occurrences of drought months (Fig. 17). Under RCP 4.5 and RCP 8.5, increase in the number of drought occurrences found to be more prevalent in mid-future and far-future for the majority of the country except for north-eastern India, southern-peninsula, and Mountainous region of northern India. An increased number of drought occurrences unfolding in projected scenarios and coupled with increased severity (Fig. 11, Fig. 13), increased areal spread (Fig. 14), and increased duration of drought months (Fig. 15) and increased average drought length (Fig. 16) outlines the future challenges in the water resource management. Worsening drought situations can be attributed to the increasing water deficit conditions under warming scenarios that can be linked to higher potential evapotranspiration demand. Though the SPEI-3 gives an insight into water stress conditions in the context of agriculture, a more detailed consideration of crop phenology is required to study the implication of drought on crop production (Zhang et al., 2017). The present study focuses on characterization of meteorological drought under warming future scenario by taking rainfall and temperature both into account. Drawing inferences on regional crop yield under altering dynamics of short-term droughts are beyond the scope of present work and can be taken up in further studies.

\section{Conclusion}

Drought characterization under projected climatic scenarios under RCP 4.5 and RCP 8.5 using a multiscalar drought index SPEI was performed over India. SPEI-3 is selected to study the drought as it corresponds to the majority of crop growing duration, hence, inferences made using SPEI could be used in agricultural decision making. However, a comprehensive approach involving information regarding crop phenology, crop yield data, cropped area, irrigation approach (i.e., rainfed or irrigated) are required to have in-depth insight on implication of drought induced water stress on crop production. It is also worth mentioning that present study

This article is protected by copyright. All rights reserved. 
utilizes the most commonly Hargreaves method to estimate PET for SPEI estimation in warming scenarios as data limitation discard the use of more robust Penman-Monteith method. Though these methods have been widely applied in warming climate scenario, evaluating the efficacy of different PET estimation methods to analyze future droughts using SPEI can be the focus of future studies, given the data is readily available.

A total of 9 GCMs were used to prepare an MME of rainfall and temperature for studying the drought conditions. MME was prepared based on the ability of GCMs in resolving the climatic cycle for different homogeneous regions of India, namely, Hilly Regions (HR), Central Northeast (CNE), Northeast (NE), Northwest (NW), West Central (WC), and Peninsula (PS) as defined by IITM, Pune. Out of used 9 GCMs, 5 GCMs were employed for CNE region, 2 GCMs for HR region, 4 GCMs for NE region, 3 GCMs for NW region, and 4 GCMs for WC region for the preparation of MME rainfall and temperature using Taylor diagram statistics. Prepared MME was found to capture the seasonal cycle of the regions with reasonable accuracy while comparing with IMD data. The present study revealed a high likelihood of above moderate drought conditions in warming climate under RCP 4.5 and RCP 8.5 scenarios. Area affected with above moderate drought conditions shows rising trend contrary to area affected from moderate drought under projected scenarios; these trends were further found to be significant at $5 \%$ significance level in long-term (2010-2099). Average drought length is also found to be increasing in nearfuture (2010-2039), mid-future (2040-2069), and far-future (2070-2099) compared to reference period (1976-2005). Similarly, increased occurrences of drought months were also found to be persistent. Mann-Kendal trend test revealed a significant increasing trend in the drought severity and duration over the majority of India in long-run (i.e., 2010-2099), however, in smaller time frames, trend were predominantly found to be non-significant. A frequency analysis of drought severity and analysis of average length of drought months in small time frames indicate the noticeable increase in severity and the average length of drought in each succeeding time-frame i.e., near-future, mid-future, and far-future under both the scenarios. This can be attributed to the long-term significant increases in drought severity and duration. To summarize, there is a high likelihood of increased drought situation under warming climate scenario. More area would be affected with above moderate drought conditions i.e., severe and extreme droughts that may have serious implication in regional water availability.

This article is protected by copyright. All rights reserved. 


\section{Acknowledgements}

This work is supported by Information Technology Research Academy (ITRA), Government of India under ITRA-Water Grant ITRA/15(69)/WATER/M2M/01. We acknowledge the World Climate Research Programme's Working Group on Coupled Modelling, which is responsible for CMIP, and we thank the climate modeling groups (listed in Table 1 of this paper). We express our sincere gratitude to India Meteorological Department (IMD), Pune for providing high resolution gridded rainfall and temperature data.

\section{Reference}

Akhter J, Das L, Deb A. 2017. CMIP5 ensemble-based spatial rainfall projection over homogeneous zones of India. Climate Dynamics. Springer Berlin Heidelberg 49(5-6): 1885-1916. DOI: 10.1007/s00382-016-3409-8.

Allen RG, Pereira LS, Raes D, Smith M. 1998. FAO Irrigation and Drainage Paper No. 56. . DOI: 10.1016/j.eja.2010.12.001.

Bandyopadhyay A, Bhadra A, Raghuwanshi NS, Singh R. 2009. Temporal Trends in Estimates of Reference Evapotranspiration over India. Journal of Hydrologic Engineering 14(5): 508-515. DOI: 10.1061/(ASCE)HE.1943-5584.0000006.

Bandyopadhyay A, Bhadra A, Swarnakar RK, Raghuwanshi NS, Singh R. 2012. Estimation of reference evapotranspiration using a user-friendly decision support system: DSS_ET. Agricultural and Forest Meteorology. Elsevier 154-155: 19-29. DOI: 10.1016/J.AGRFORMET.2011.10.013.

Beria H, Nanda T, Singh Bisht D, Chatterjee C. 2017. Does the GPM mission improve the systematic error component in satellite rainfall estimates over TRMM? An evaluation at a pan-India scale. Hydrology and Earth System Sciences 21(12): 6117-6134. DOI: 10.5194/hess-21-6117-2017.

Bisht DS, Chatterjee C, Kalakoti S, Upadhyay P, Sahoo M, Panda A. 2016. Modeling urban floods and drainage using SWMM and MIKE URBAN: a case study. Natural Hazards. Springer Netherlands 84(2): 749-776. DOI: 10.1007/s11069-016-2455-1.

Bisht DS, Chatterjee C, Raghuwanshi NS, Sridhar V. 2017. An analysis of precipitation climatology over Indian urban agglomeration. Theoretical and Applied Climatology. Springer Vienna 1-16. DOI: 10.1007/s00704-017-2200-z.

This article is protected by copyright. All rights reserved. 
Bisht DS, Chatterjee C, Raghuwanshi NS, Sridhar V. 2018. Spatio-temporal trends of rainfall across Indian river basins. Theoretical and Applied Climatology. Springer Vienna 132(12): 419-436. DOI: 10.1007/s00704-017-2095-8.

Bonsal BR, Cuell C, Wheaton E, Sauchyn DJ, Barrow E. 2017. An assessment of historical and projected future hydro-climatic variability and extremes over southern watersheds in the Canadian Prairies. International Journal of Climatology. Wiley-Blackwell 37(10): 39343948. DOI: $10.1002 /$ joc.4967.

Burke EJ, Brown SJ. 2008. Evaluating Uncertainties in the Projection of Future Drought. Journal of Hydrometeorology 9: 292-299. DOI: 10.1175/2007JHM929.1.

Chakraborty A, Seshasai MVR, Rao SVCK, Dadhwal VK. 2017. Geo-spatial analysis of temporal trends of temperature and its extremes over India using daily gridded $\left(1^{\circ} \times 1^{\circ}\right)$ temperature data of 1969-2005. Theoretical and Applied Climatology. Springer Vienna 130(1-2): 133-149. DOI: 10.1007/s00704-016-1869-8.

Chen H, Sun J. 2017. Characterizing present and future drought changes over eastern China. International Journal of Climatology. John Wiley \& Sons, Ltd 37: 138-156. DOI: 10.1002/joc. 4987.

Dai A. 2011. Characteristics and trends in various forms of the Palmer Drought Severity Index during 1900-2008. Journal of Geophysical Research. Wiley-Blackwell 116(D12): D12115. DOI: 10.1029/2010JD015541.

Das L, Annan JD, Hargreaves JC, Emori S. 2012. Improvements over three generations of climate model simulations for eastern India. Climate Research 51(3): 201-216. DOI: 10.3354/cr01064.

Deshpande NR, Kothawale DR, Kulkarni A. 2016. Changes in climate extremes over major river basins of India. International Journal of Climatology n/a-n/a. DOI: 10.1002/joc.4651.

Dhage PM, Raghuwanshi NS, Singh R, Mishra A. 2016. Development of daily temperature scenarios and their impact on paddy crop evapotranspiration in Kangsabati command area. Theoretical and Applied Climatology. DOI: 10.1007/s00704-016-1743-8.

Dibike Y, Prowse T, Bonsal B, O’Neil H. 2017. Implications of future climate on water availability in the western Canadian river basins. International Journal of Climatology. Wiley-Blackwell 37(7): 3247-3263. DOI: 10.1002/joc.4912.

Feng S, Trnka M, Hayes M, Zhang Y, Feng S, Trnka M, Hayes M, Zhang Y. 2017. Why Do

This article is protected by copyright. All rights reserved. 
Different Drought Indices Show Distinct Future Drought Risk Outcomes in the U.S. Great Plains? Journal of Climate 30(1): 265-278. DOI: 10.1175/JCLI-D-15-0590.1.

Gao X, Zhao Q, Zhao X, Wu P, Pan W, Gao X, Sun M. 2017. Temporal and spatial evolution of the standardized precipitation evapotranspiration index (SPEI) in the Loess Plateau under climate change from 2001 to 2050. Science of The Total Environment. Elsevier 595: 191200. DOI: 10.1016/J.SCITOTENV.2017.03.226.

Hamed KH, Rao AR. 1998. A Modified Mann Kendal trend test for autocorrelated data. Journal of Hydrology 204(182-196).

Hayes MJ, Svoboda MD, Wilhite DA, Vanyarkho O V. 1999. Monitoring the 1996 Drought Using the Standardized Precipitation Index. Bulletin of the American Meteorological Society 80(3): 429-438. DOI: 10.1175/1520-0477(1999)080<0429:MTDUTS>2.0.CO;2.

Hosking JRM, Wallis JR. 1997. Regional frequency analysis-An approach based on L-moments. Cambridge University Press: New York.

Huang J, Zhai J, Jiang T, Wang Y, Li X, Wang R, Xiong M, Su B, Fischer T. 2018. Analysis of future drought characteristics in China using the regional climate model CCLM. Climate Dynamics. Springer Berlin Heidelberg 50(1-2): 507-525. DOI: 10.1007/s00382-0173623-z.

IPCC. 2012. Managing the Risks of Extreme Events and Disasters to Advance Climate Change Adaptation: in Special Report of the Intergovernmental Panel on Climate Change. . DOI: 10.1017/CBO9781139177245.

Jena PP, Chatterjee C, Pradhan G, Mishra A. 2014. Are recent frequent high floods in Mahanadi basin in eastern India due to increase in extreme rainfalls? Journal of Hydrology. Elsevier B.V. 517: 847-862. DOI: 10.1016/j.jhydrol.2014.06.021.

Kang H, Sridhar V. 2017. Combined statistical and spatially distributed hydrological model for evaluating future drought indices in Virginia. Journal of Hydrology: Regional Studies. Elsevier 12: 253-272. DOI: 10.1016/J.EJRH.2017.06.003.

Kang H, Sridhar V. 2018. Assessment of Future Drought Conditions in the Chesapeake Bay Watershed. JAWRA Journal of the American Water Resources Association. Wiley/Blackwell (10.1111) 54(1): 160-183. DOI: 10.1111/1752-1688.12600.

Khan MI, Liu D, Fu Q, Saddique Q, Faiz MA, Li T, Qamar MU, Cui S, Cheng C. 2017. Projected Changes of Future Extreme Drought Events under Numerous Drought Indices

This article is protected by copyright. All rights reserved. 
in the Heilongiiang Province of China. Water Resources Management. Springer Netherlands 31(12): 3921-3937. DOI: 10.1007/s11269-017-1716-4.

Kumar KN, Rajeevanb M, Pai DS, Srivastava AK, Preethi B. 2013. On the observed variability of monsoon droughts over India. Weather and Climate Extremes 42-50. DOI: 10.1016/j.wace.2013.07.006.

Kumar R, Chatterjee C. 2005. Regional Flood Frequency Analysis Using L-Moments for North Brahmaputra Region of India. Journal of Hydrologic Engineering 10(1): 1-7. DOI: 10.1061/(ASCE)1084-0699(2005)10:1(1).

Kumar R, Chatterjee C. 2011. Development of Regional Flood Frequency Relationships for Gauged and Ungauged Catchments Using L-Moments. In Extremis. Springer Berlin Heidelberg: Berlin, Heidelberg, 105-127. DOI: 10.1007/978-3-642-14863-7.

Lee J-H, Park S-Y, Kim J-S, Sur C, Chen J. 2018. Extreme drought hotspot analysis for adaptation to a changing climate: Assessment of applicability to the five major river basins of the Korean Peninsula. International Journal of Climatology. Wiley-Blackwell 1-8. DOI: $10.1002 /$ joc.5532.

Li H, Sheffield J, Wood EF. 2010. Bias correction of monthly precipitation and temperature fields from Intergovernmental Panel on Climate Change AR4 models using equidistant quantile matching. Journal of Geophysical Research. Wiley-Blackwell 115(D10): 1-20. DOI: $10.1029 / 2009 J D 012882$.

Liu Z, Wang Y, Shao M, Jia X, Li X. 2016. Spatiotemporal analysis of multiscalar drought characteristics across the Loess Plateau of China. Journal of Hydrology 534: 281-299. DOI: 10.1016/j.jhydrol.2016.01.003.

Lopez-Bustins JA, Pascual D, Pla E, Retana J. 2013. Future variability of droughts in three Mediterranean catchments. Natural Hazards. Springer Netherlands 69(3): 1405-1421. DOI: 10.1007/s11069-013-0754-3.

Mallya G, Mishra V, Niyogi D, Tripathi S, Govindaraju RS. 2016. Trends and variability of droughts over the Indian monsoon region. Weather and Climate Extremes 12: 43-68. DOI: 10.1016/j.wace.2016.01.002.

Mckee TB, Doesken NJ, Kleist J. 1993. The Relationship of Drought Frequency and Duration to Time Scales. Eighth Conference on Applied Climatology. Anahein, California.

Meher JK, Das L, Akhter J, Benestad RE, Mezghani A. 2017. Performance of CMIP3 and

This article is protected by copyright. All rights reserved. 
CMIP5 GCMs to simulate observed rainfall characteristics over the western Himalayan region. Journal of Climate 30(19): 7777-7799. DOI: 10.1175/JCLI-D-16-0774.1.

Ministry of Finance- India. 2018. Economic Survey 2017-18. .

Mishra A, Liu SC. 2014. Changes in precipitation pattern and risk of drought over India in the context of global warming. Journal of Geophysical Research : Atmospheres 119: 78337841. DOI: 10.1002/2014JD021471.

Mishra AK, Desai VR. 2005. Spatial and temporal drought analysis in the Kansabati river basin, India. International Journal of River Basin Management 3(1): 31-41. DOI: 10.1080/15715124.2005.9635243.

Mishra AK, Singh VP. 2009. Analysis of drought severity-area-frequency curves using a general circulation model and scenario uncertainty. Journal of Geophysical Research 114(D6): D06120. DOI: 10.1029/2008JD010986.

Mishra AK, Singh VP. 2011. Drought modeling - A review. Journal of Hydrology 403(1-2): 157-175. DOI: 10.1016/j.jhydrol.2011.03.049.

Mishra V, Shah R, Thrasher B. 2014. Soil Moisture Droughts under the Retrospective and Projected Climate in India. Journal of Hydrometeorology 141006071153004. DOI: 10.1175/JHM-D-13-0177.1.

Nam W-H, Hayes MJ, Svoboda MD, Tadesse T, Wilhite DA. 2015. Drought hazard assessment in the context of climate change for South Korea. Agricultural Water Management 160: 106-117. DOI: 10.1016/j.agwat.2015.06.029.

Naresh Kumar M, Murthy CS, Sesha Sai MVR, Roy PS. 2012. Spatiotemporal analysis of meteorological drought variability in the Indian region using standardized precipitation index. Meteorological Applications. John Wiley \& Sons, Ltd. 19(2): 256-264. DOI: 10.1002/met.277.

Oguntunde PG, Abiodun BJ, Lischeid G. 2017. Impacts of climate change on hydrometeorological drought over the Volta Basin, West Africa. Global and Planetary Change. Elsevier 155: 121-132. DOI: 10.1016/J.GLOPLACHA.2017.07.003.

Ojha R, Kumar D, Sharma A, Mehrotra R. 2013. Assessing Severe Drought and Wet Events over India in a Future Climate Using a Nested Bias Correction Approach. Journal of Hydrologic ... 18(7): 760-772. DOI: 10.1061/(ASCE)HE.1943-5584.0000585.

Osuch M, Romanowicz RJ, Lawrence D, Wong WK. 2016. Trends in projections of standardized

This article is protected by copyright. All rights reserved. 
precipitation indices in a future climate in Poland. Hydrology and Earth System Sciences. Copernicus GmbH 20(5): 1947-1969. DOI: 10.5194/hess-20-1947-2016.

Pai DS, Sridhar L, Rajeevan M, Sreejith OP, Satbhai NS, Mukhopadyay B. 2014. Development of a new high spatial resolution $\left(0.25^{\circ} \times 0.25^{\circ}\right)$ Long Period ( 1901-2010 ) daily gridded rainfall data set over India and its comparison with existing data sets over the region. Mausam 65(1): 1-18.

Paul PK, Kumari N, Panigrahi N, Mishra A, Singh R. 2018. Implementation of cell-to-cell routing scheme in a large scale conceptual hydrological model. Environmental Modelling \& Software. Elsevier 101: 23-33. DOI: 10.1016/J.ENVSOFT.2017.12.003.

Rao AR, Hamed KH, Chen HL. 2003. Nonstationarities in Hydrologic and Environmental Time Series. Kluwer Academic Publishers: The Netherlands.

Rhee J, Cho J, Rhee J, Cho J. 2016. Future Changes in Drought Characteristics: Regional Analysis for South Korea under CMIP5 Projections. Journal of Hydrometeorology 17(1): 437-451. DOI: 10.1175/JHM-D-15-0027.1.

Salvi K, S. K, Ghosh S. 2013. High-resolution multisite daily rainfall projections in India with statistical downscaling for climate change impacts assessment. Journal of Geophysical Research: Atmospheres 118(9): 3557-3578. DOI: 10.1002/jgrd.50280.

Samantaray D, Chatterjee C, Singh R, Gupta PK, Panigrahy S. 2015. Flood risk modeling for optimal rice planning for delta region of Mahanadi river basin in India. Natural Hazards. Springer Netherlands 76(1): 347-372. DOI: 10.1007/s11069-014-1493-9.

Sen PK. 1968. Estimates of the regression coefficient based on Kendall's tau. Journal of the American Statistical Association. Taylor \& Francis Group 63(324): 1379-1389.

Sharma S, Mujumdar P. 2017. Increasing frequency and spatial extent of concurrent meteorological droughts and heatwaves in India. Scientific Reports. Nature Publishing Group 7(1). DOI: 10.1038/s41598-017-15896-3.

Smirnov O, Zhang M, Xiao T, Orbell J, Lobben A, Gordon J. 2016. The relative importance of climate change and population growth for exposure to future extreme droughts. Climatic Change. Springer Netherlands 138(1-2): 41-53. DOI: 10.1007/s10584-016-1716-z.

Smitha PS, Narasimhan B, Sudheer KP, Annamalai H. 2018. An improved bias correction method of daily rainfall data using a sliding window technique for climate change impact assessment. Journal of Hydrology. Elsevier 556: 100-118. DOI:

This article is protected by copyright. All rights reserved. 
10.1016/J.JHYDROL.2017.11.010.

Spinoni J, Vogt J V., Naumann G, Barbosa P, Dosio A. 2018. Will drought events become more frequent and severe in Europe? International Journal of Climatology. Wiley-Blackwell 38(4): 1718-1736. DOI: 10.1002/joc.5291.

Stagge JH, Rizzi J, Tallaksen LM, Stahl K. 2015. Future meteorological drought: projections of regional climate models for Europe. Oslo.

Taylor KE. 2001. Summarizing multiple aspects of model performance in a single diagram. Journal of Geophysical Research: Atmospheres. Wiley-Blackwell 106(D7): 7183-7192. DOI: 10.1029/2000JD900719.

Theil H. 1950. A rank-invariant method of linear and polynomial regression analysis. Indag. math 12: 85.

Thilakarathne M, Sridhar V. 2017. Characterization of future drought conditions in the Lower Mekong River Basin. Weather and Climate Extremes. Elsevier 17: 47-58. DOI: 10.1016/J.WACE.2017.07.004.

Thomas T, Nayak PC, Ghosh NC. 2015. Spatiotemporal Analysis of Drought Characteristics in the Bundelkhand Region of Central India using the Standardized Precipitation Index. Journal of Hydrologic Engineering 20(11). DOI: 10.1061/(ASCE)HE.19435584.0001189.

Thrasher B, Maurer EP, Mckellar C, Duffy PB. 2012. Technical Note: Bias correcting climate model simulated daily temperature extremes with quantile mapping. Hydrol. Earth Syst. Sci 16: 3309-3314. DOI: 10.5194/hess-16-3309-2012.

Törnros T, Menzel L. 2014. Addressing drought conditions under current and future climates in the Jordan River region. Hydrol. Earth Syst. Sci 18: 305-318. DOI: 10.5194/hess-18-3052014.

Trenberth KE, Dai A, van der Schrier G, Jones PD, Barichivich J, Briffa KR, Sheffield J. 2013. Global warming and changes in drought. Nature Climate Change. Nature Publishing Group 4(1): 17-22. DOI: 10.1038/nclimate2067.

Vicente-Serrano SM, Beguería S, López-Moreno JI. 2010. A Multiscalar Drought Index Sensitive to Global Warming: The Standardized Precipitation Evapotranspiration Index. Journal of Climate 23(7): 1696-1718. DOI: 10.1175/2009JCLI2909.1.

Wang A, Lettenmaier DP, Sheffield J. 2011. Soil moisture drought in China, 1950-2006. Journal

This article is protected by copyright. All rights reserved. 
of Climate 24(2010): 3257-3271. DOI: 10.1175/2011JCLI3733.1.

Wang L, Chen W, Zhou W. 2014. Assessment of future drought in Southwest China based on CMIP5 multimodel projections. Advances in Atmospheric Sciences. Science Press 31(5): 1035-1050. DOI: 10.1007/s00376-014-3223-3.

Weigel AP, Liniger MA, Appenzeller C. 2010. Risks of Model Weighting in Multimodel Climate Projections. Journal of Climate 23(15): 4175-4191. DOI: 10.1175/2010JCLI3594.1.

Wu C, Xian Z, Huang G. 2016. Meteorological drought in the Beijiang River basin, South China: current observations and future projections. Stochastic Environmental Research and Risk Assessment. Springer Berlin Heidelberg 30(7): 1821-1834. DOI: 10.1007/s00477-0151157-7.

Yevjevich V. 1967. An Objective Approach to Definitions and Investigations of Continental Hydrologic Droughts. Hydrology papers, Colorado State University 23.

Yu M, Li Q, Hayes MJ, Svoboda MD, Heim RR. 2014. Are droughts becoming more frequent or severe in China based on the standardized precipitation evapotranspiration index: 19512010? International Journal of Climatology 34: 545-558. DOI: 10.1002/joc.3701.

Zhang X, Obringer R, Wei C, Chen N, Niyogi D. 2017. Droughts in India from 1981 to 2013 and Implications to Wheat Production. Scientific Reports. Nature Publishing Group 7. DOI: $10.1038 /$ srep44552.

Zhang Y, Yu Z, Niu H. 2018. Standardized Precipitation Evapotranspiration Index is highly correlated with total water storage over China under future climate scenarios. Atmospheric Environment. Pergamon 194: 123-133. DOI: 10.1016/J.ATMOSENV.2018.09.028.

\section{Figure Captions}

Fig. 1 Homogeneous monsoon regions of India

Fig. 2 Drought events and characteristics using 'run theory'

This article is protected by copyright. All rights reserved. 
Fig. 3 Box and Whisker plots showing rainfall variability across the regions in comparison to all India scale $(\mathrm{AI}=$ all India scale, $\mathrm{CNE}=$ Central Northeast, $\mathrm{HR}=$ Hilly Regions, $\mathrm{NE}=$ Northeast , $\mathrm{NW}=$ Northwest, WS $=$ West Central, and PS = Peninsular India $)$

Fig. 4 Taylor diagram for statistical comparison of IMD mean monthly precipitation with 9 bias corrected model estimates during training period (1976-2005) for homogeneous monsoon regions of India

Fig. 5 Taylor diagram for statistical comparison of IMD mean monthly precipitation with 9 bias corrected model estimates during testing period (1951-1975) for homogeneous monsoon regions of India

Fig. 6 Pattern comparison for training period (1976-2005) for homogeneous regions. Mean monthly bias-corrected rainfall for selected GCMs and IMD [left panel], Error plots of mean monthly rainfall [center panel], and seasonal cycle of IMD and MME rainfall [right panel], all values are in $\mathrm{mm}$

Fig. 7 Same as Fig. 4 except for testing period (1951-1975)

Fig. 8 Hovmoller diagram depicting annual cycle of rainfall climatology $(\mathrm{mm} / \mathrm{month})$ during training and testing period for IMD and MME data

Fig. 9 Comparison of seasonal cycle of Tmax and Tmin of IMD temperature with bias-corrected (BC) MME for training period and projected RCP 4.5 scenario

Fig. 10 Comparison of seasonal cycle of Tmax and Tmin of IMD temperature with biascorrected (BC) MME for training period and projected RCP 8.5 scenario

Fig. 11 Trend in the magnitude of SPEI-3drought severity. NS denotes 'Non-Significant' trend; Increasing and decreasing trends are shown in red and blue color, respectively

Fig. 12 Identified best fit distribution using 1-moments for frequency analysis (GLO = Generalized Logistic, GEV = Generalized Extreme Value, GNO = Generalized Normal, PE3 = Pearson type-III, GPA = Generalized Pareto, WAK = Wakeby) of drought severity

This article is protected by copyright. All rights reserved. 
Fig. 13 Comparison of spatial distribution of 25-year return period SPEI-3 drought severity in reference period and projected scenarios

Fig. 14 Trend in area under 'moderate droughts' and 'above moderate droughts' in historical, RCP 4.5, and RCP 8.5 scenarios. In left panels fitted solid black lines show the Theil-Sen's slope for historical (1976-2005) period. In right panel Thiel-Sen's slope is shown in solid red, solid blue, solid green, and dotted black for \% area under 'moderate drought' during near-future (2010-2039), mid-future (2040-2069), far-future (2070-2099), and entire projected time period (2010-2099), respectively.

Fig. 15 Trend in the SPEI-3 drought duration. NS denotes 'Non-Significant' trend; Increasing and decreasing trends are shown in red and blue color, respectively.

Fig. 16 Comparison of average length of SPEI-3 drought months in reference period and projected scenarios

Fig. 17 Comparison of occurrences of SPEI-3 drought months in reference period and projected scenarios

Fig. S1 Hovmoller diagram depicting annual cycle of maximum temperature climatology $\left({ }^{\circ} \mathrm{C}\right)$ during training and testing period for IMD and MME data

Fig. S2 Hovmoller diagram depicting annual cycle of minimum temperature climatology $\left({ }^{\circ} \mathrm{C}\right)$ during training and testing period for IMD and MME data.

Table 1 List of GCMs used in this study from CMIP5 project with their developing organization and spatial resolution

\section{\begin{tabular}{l|l|l} 
S.No. & Model & Organization \\
\hline
\end{tabular}}

\section{Spatial}

This article is protected by copyright. All rights reserved. 


\begin{tabular}{|c|c|c|c|}
\hline & & & $\begin{array}{l}\text { Resolution } \\
\text { (latitude } \times \\
\text { longitude) } \\
\end{array}$ \\
\hline 1 & $\begin{array}{l}\text { BCC- } \\
\text { CSM1.1(m) }\end{array}$ & $\begin{array}{l}\text { Beijing Climate Center, China Meteorological } \\
\text { Administration }\end{array}$ & $1.125^{\circ} \times 1.125^{\circ}$ \\
\hline 2 & $\begin{array}{l}\text { HadGEM2- } \\
\text { AO }\end{array}$ & $\begin{array}{l}\text { Met Office Hadley Centre, UK (additional } \\
\text { HadGEM2-ES realizations contributed by Instituto } \\
\text { Nacional de Pesquisas Espaciais) }\end{array}$ & $1.25^{\circ} \times 1.875^{\circ}$ \\
\hline 3 & GFDL-CM3 & Geophysical Fluid Dynamics Laboratory, USA & $2^{\circ} \times 2.5^{\circ}$ \\
\hline 4 & $\begin{array}{l}\text { GFDL- } \\
\text { ESM2G }\end{array}$ & Geophysical Fluid Dynamics Laboratory, USA & $2^{\circ} \times 2.5^{\circ}$ \\
\hline 5 & $\begin{array}{l}\text { IPSL-CM5A- } \\
\text { LR }\end{array}$ & Institut Pierre-Simon Laplace, France & $1.875^{\circ} \times 3.75^{\circ}$ \\
\hline 6 & $\begin{array}{l}\text { IPSL-CM5A- } \\
\text { MR }\end{array}$ & Institut Pierre-Simon Laplace, France & $1.25^{\circ} \times 2.5^{\circ}$ \\
\hline 7 & MIROC5 & $\begin{array}{l}\text { Atmosphere and Ocean Research Institute (The } \\
\text { University of Tokyo), National Institute for } \\
\text { Environmental Studies, and Japan Agency for } \\
\text { Marine-Earth Science and Technology }\end{array}$ & $1.4^{\circ} \times 1.4^{\circ}$ \\
\hline 8 & $\begin{array}{l}\text { MIROC- } \\
\text { ESM-CHEM }\end{array}$ & $\begin{array}{l}\text { Japan Agency for Marine-Earth Science and } \\
\text { Technology, Atmosphere and Ocean Research } \\
\text { Institute (The University of Tokyo), and National } \\
\text { Institute for Environmental Studies }\end{array}$ & $2.8^{\circ} \times 2.8^{\circ}$ \\
\hline 9 & NorESM1-M & Norwegian Climate Centre & $1.875^{\circ} \times 2.5^{\circ}$ \\
\hline
\end{tabular}

Table 2 Drought classification criteria for different SPEI values

\begin{tabular}{|c|c|}
\hline SPEI values & Category \\
\hline$>2.0$ & Extremely wet \\
\hline 1.5 to 1.99 & Severely wet \\
\hline 1.0 to 1.49 & Moderately wet \\
\hline-0.99 to 0.99 & Near normal \\
\hline-1.0 to -1.49 & Moderately dry \\
\hline-1.5 to -1.99 & Severely dry \\
\hline$<-2.0$ & Extremely dry \\
\hline
\end{tabular}

This article is protected by copyright. All rights reserved. 
Table 3 Taylor diagram statistics for identification of suitable set of GCMs for MME development (Statistics of selected models for respective homogeneous regions are shown in shaded background in bold font)

\begin{tabular}{|c|c|c|c|c|c|c|c|c|c|c|c|c|}
\hline & \multicolumn{11}{|c|}{ Correlation Coefficient (CC) } & \\
\hline & \multicolumn{6}{|c|}{ Training (1976-2005) } & \multicolumn{6}{|c|}{ Testing (1951-1975) } \\
\hline & CNE & HR & NE & NW & PS & WC & CNE & HR & NE & NW & PS & WC \\
\hline IMD & 1 & 1 & 1 & 1 & 1 & 1 & 1 & 1 & 1 & 1 & 1 & 1 \\
\hline $\begin{array}{l}\text { BCC- } \\
\text { CSM1.1(m } \\
\text { ) }\end{array}$ & 0.99 & $\begin{array}{c}0.9 \\
4\end{array}$ & 0.97 & $\begin{array}{c}0.9 \\
7\end{array}$ & $\begin{array}{c}0.9 \\
8\end{array}$ & 0.99 & 0.99 & $\begin{array}{c}0.9 \\
2\end{array}$ & 0.98 & $\begin{array}{c}0.9 \\
7\end{array}$ & $\begin{array}{c}0.9 \\
7\end{array}$ & $\mathbf{1}$ \\
\hline $\begin{array}{l}\text { HadGEM2- } \\
\text { AO }\end{array}$ & 0.94 & $\begin{array}{c}0.9 \\
4\end{array}$ & 0.99 & $\begin{array}{c}0.9 \\
7\end{array}$ & $\begin{array}{c}0.8 \\
8\end{array}$ & 0.93 & 0.93 & $\begin{array}{c}0.9 \\
3\end{array}$ & 0.99 & $\begin{array}{c}0.9 \\
2\end{array}$ & $\begin{array}{c}0.9 \\
3\end{array}$ & 0.94 \\
\hline $\begin{array}{l}\text { GFDL- } \\
\text { CM3 }\end{array}$ & 0.98 & $\begin{array}{c}0.8 \\
9\end{array}$ & 0.98 & 0.9 & $\begin{array}{c}0.9 \\
5\end{array}$ & 0.98 & 0.98 & $\begin{array}{c}0.8 \\
4\end{array}$ & 0.98 & $\begin{array}{c}0.9 \\
1\end{array}$ & $\begin{array}{c}0.9 \\
5\end{array}$ & 0.99 \\
\hline $\begin{array}{l}\text { GFDL- } \\
\text { ESM2G }\end{array}$ & 1 & $\begin{array}{c}0.9 \\
3\end{array}$ & 0.97 & $\begin{array}{c}0.8 \\
2\end{array}$ & $\begin{array}{c}0.9 \\
6\end{array}$ & 0.97 & 0.98 & $\begin{array}{c}0.9 \\
4\end{array}$ & 0.98 & $\begin{array}{c}0.8 \\
8\end{array}$ & $\begin{array}{c}0.9 \\
7\end{array}$ & 0.99 \\
\hline $\begin{array}{l}\text { IPSL- } \\
\text { CM5A-LR }\end{array}$ & 0.83 & $\begin{array}{c}0.7 \\
7\end{array}$ & 0.86 & $\begin{array}{c}0.5 \\
9\end{array}$ & $\begin{array}{c}0.8 \\
4\end{array}$ & 0.79 & 0.86 & $\begin{array}{c}0.7 \\
8\end{array}$ & 0.82 & $\begin{array}{c}0.6 \\
9\end{array}$ & $\begin{array}{c}0.8 \\
6\end{array}$ & 0.79 \\
\hline $\begin{array}{l}\text { IPSL- } \\
\text { CM5A-MR }\end{array}$ & 0.9 & $\begin{array}{c}0.8 \\
6\end{array}$ & 0.94 & $\begin{array}{c}0.5 \\
7\end{array}$ & $\begin{array}{c}0.8 \\
8\end{array}$ & 0.81 & 0.89 & $\begin{array}{c}0.8 \\
5\end{array}$ & 0.91 & $\begin{array}{c}0.7 \\
1\end{array}$ & $\begin{array}{c}0.9 \\
1\end{array}$ & 0.8 \\
\hline MIROC5 & 0.97 & $\begin{array}{c}0.9 \\
8\end{array}$ & 0.94 & $\begin{array}{c}0.9 \\
8\end{array}$ & $\begin{array}{c}0.9 \\
5\end{array}$ & 0.99 & 0.96 & $\begin{array}{c}0.9 \\
6\end{array}$ & 0.95 & 0.9 & $\begin{array}{c}0.9 \\
3\end{array}$ & 0.99 \\
\hline $\begin{array}{l}\text { MIROC- } \\
\text { ESM- } \\
\text { CHEM }\end{array}$ & 0.93 & 0.9 & 0.95 & $\begin{array}{c}0.9 \\
7\end{array}$ & $\begin{array}{c}0.9 \\
6\end{array}$ & 0.95 & 0.91 & $\begin{array}{c}0.9 \\
3\end{array}$ & 0.95 & $\begin{array}{c}0.9 \\
5\end{array}$ & $\begin{array}{c}0.9 \\
7\end{array}$ & 0.94 \\
\hline \multirow[t]{4}{*}{$\begin{array}{l}\text { NorESM1- } \\
\text { M }\end{array}$} & 0.97 & $\begin{array}{c}0.9 \\
7\end{array}$ & 0.99 & $\begin{array}{c}0.8 \\
7\end{array}$ & $\begin{array}{c}0.9 \\
3\end{array}$ & 0.95 & 0.98 & $\begin{array}{c}0.9 \\
7\end{array}$ & 0.99 & $\begin{array}{c}0.9 \\
7\end{array}$ & $\begin{array}{c}0.9 \\
5\end{array}$ & 0.97 \\
\hline & \multicolumn{12}{|c|}{ Standard Deviation (SD) } \\
\hline & \multicolumn{6}{|c|}{ Training (1976-2005) } & \multicolumn{6}{|c|}{ Testing (1951-1975) } \\
\hline & CNE & HR & NE & $\mathbf{N W}$ & PS & $\mathbf{W C}$ & $\mathrm{CNE}$ & HR & $\mathbf{N E}$ & $\mathbf{N W}$ & PS & WC \\
\hline IMD & $\begin{array}{c}113 . \\
5\end{array}$ & $\begin{array}{c}84 . \\
1\end{array}$ & $\begin{array}{c}164 . \\
2\end{array}$ & $\begin{array}{c}64 . \\
9\end{array}$ & $\begin{array}{c}69 . \\
6\end{array}$ & $\begin{array}{c}114 . \\
6\end{array}$ & $\begin{array}{c}117 . \\
4\end{array}$ & $\begin{array}{c}91 . \\
8\end{array}$ & $\begin{array}{c}156 . \\
3\end{array}$ & $\begin{array}{c}68 . \\
2\end{array}$ & $\begin{array}{c}75 . \\
3\end{array}$ & $\begin{array}{c}118 . \\
5\end{array}$ \\
\hline $\begin{array}{l}\text { BCC- } \\
\text { CSM1.1(m } \\
)\end{array}$ & 126 & $\begin{array}{c}79 . \\
4\end{array}$ & 188 & $\begin{array}{c}62 . \\
2\end{array}$ & $\begin{array}{c}74 . \\
1\end{array}$ & $\begin{array}{c}122 . \\
8\end{array}$ & $\begin{array}{c}126 . \\
1\end{array}$ & $\begin{array}{c}78 . \\
8\end{array}$ & $\begin{array}{c}191 . \\
1\end{array}$ & $\begin{array}{c}61 . \\
9\end{array}$ & $\begin{array}{c}75 . \\
5\end{array}$ & $\begin{array}{c}122 . \\
2\end{array}$ \\
\hline $\begin{array}{l}\text { HadGEM2- } \\
\text { AO }\end{array}$ & $\begin{array}{c}136 . \\
4\end{array}$ & $\begin{array}{c}97 . \\
1\end{array}$ & 166 & $\begin{array}{c}80 . \\
5\end{array}$ & $\begin{array}{c}78 . \\
9\end{array}$ & $\begin{array}{c}139 . \\
3\end{array}$ & $\begin{array}{c}137 . \\
4\end{array}$ & $\begin{array}{c}98 . \\
1\end{array}$ & $\begin{array}{c}165 . \\
7\end{array}$ & $\begin{array}{c}83 . \\
3\end{array}$ & $\begin{array}{c}78 . \\
4\end{array}$ & $\begin{array}{c}137 . \\
3\end{array}$ \\
\hline $\begin{array}{l}\text { GFDL- } \\
\text { CM3 }\end{array}$ & $\begin{array}{c}122 . \\
3\end{array}$ & $\begin{array}{c}79 . \\
3\end{array}$ & 167 & $\begin{array}{c}73 . \\
3\end{array}$ & $\begin{array}{c}78 . \\
1\end{array}$ & $\begin{array}{c}125 . \\
1\end{array}$ & $\begin{array}{c}119 . \\
1\end{array}$ & $\begin{array}{c}79 . \\
6\end{array}$ & $\begin{array}{c}167 . \\
8\end{array}$ & 76 & $\begin{array}{c}77 . \\
5\end{array}$ & $\begin{array}{c}125 . \\
2\end{array}$ \\
\hline $\begin{array}{l}\text { GFDL- } \\
\text { ESM2G }\end{array}$ & 116 & $\begin{array}{c}81 . \\
6\end{array}$ & $\begin{array}{c}176 . \\
7\end{array}$ & $\begin{array}{c}66 . \\
3\end{array}$ & $\begin{array}{c}78 . \\
2\end{array}$ & $\begin{array}{c}113 . \\
9\end{array}$ & $\begin{array}{c}114 . \\
3\end{array}$ & $\begin{array}{c}82 . \\
4\end{array}$ & $\begin{array}{c}171 . \\
2\end{array}$ & $\begin{array}{c}70 . \\
8\end{array}$ & $\begin{array}{c}76 . \\
7\end{array}$ & 117 \\
\hline
\end{tabular}

This article is protected by copyright. All rights reserved. 


\begin{tabular}{|c|c|c|c|c|c|c|c|c|c|c|c|c|}
\hline $\begin{array}{l}\text { IPSL- } \\
\text { CM5A-LR }\end{array}$ & $\begin{array}{c}154 . \\
8\end{array}$ & $\begin{array}{c}85 . \\
6\end{array}$ & $\begin{array}{c}187 . \\
9\end{array}$ & $\begin{array}{c}78 . \\
4\end{array}$ & $\begin{array}{c}96 . \\
8\end{array}$ & $\begin{array}{c}153 . \\
2\end{array}$ & 154 & $\begin{array}{c}82 . \\
7\end{array}$ & $\begin{array}{c}188 . \\
7\end{array}$ & $\begin{array}{c}75 . \\
7\end{array}$ & $\begin{array}{c}88 . \\
5\end{array}$ & $\begin{array}{c}154 . \\
2\end{array}$ \\
\hline $\begin{array}{l}\text { IPSL- } \\
\text { CM5A-MR }\end{array}$ & $\begin{array}{c}140 . \\
2\end{array}$ & $\begin{array}{c}83 . \\
3\end{array}$ & $\begin{array}{c}178 . \\
3\end{array}$ & $\begin{array}{c}77 . \\
3\end{array}$ & $\begin{array}{c}89 . \\
7\end{array}$ & $\begin{array}{c}147 . \\
5\end{array}$ & $\begin{array}{c}144 . \\
1\end{array}$ & $\begin{array}{c}81 . \\
9\end{array}$ & $\begin{array}{c}173 . \\
4\end{array}$ & $\begin{array}{c}73 . \\
4\end{array}$ & $\begin{array}{c}91 . \\
8\end{array}$ & 152 \\
\hline MIROC5 & $\begin{array}{c}116 . \\
5\end{array}$ & $\begin{array}{c}86 . \\
8\end{array}$ & $\begin{array}{c}186 . \\
2\end{array}$ & $\begin{array}{c}60 . \\
9\end{array}$ & $\begin{array}{c}73 . \\
3\end{array}$ & $\begin{array}{c}111 . \\
7\end{array}$ & $\begin{array}{c}118 . \\
5\end{array}$ & $\begin{array}{c}88 . \\
5\end{array}$ & 183 & $\begin{array}{c}62 . \\
8\end{array}$ & $\begin{array}{c}67 . \\
4\end{array}$ & $\begin{array}{c}113 . \\
3\end{array}$ \\
\hline $\begin{array}{l}\text { MIROC- } \\
\text { ESM- } \\
\text { CHEM }\end{array}$ & $\begin{array}{c}120 . \\
4\end{array}$ & 87 & $\begin{array}{c}180 . \\
4\end{array}$ & $\begin{array}{c}66 . \\
2\end{array}$ & $\begin{array}{c}82 . \\
8\end{array}$ & $\begin{array}{c}126 . \\
1\end{array}$ & $\begin{array}{c}118 . \\
9\end{array}$ & $\begin{array}{c}86 . \\
5\end{array}$ & $\begin{array}{c}182 . \\
2\end{array}$ & $\begin{array}{c}65 . \\
4\end{array}$ & $\begin{array}{c}83 . \\
9\end{array}$ & $\begin{array}{c}124 . \\
1\end{array}$ \\
\hline \multirow[t]{4}{*}{$\begin{array}{l}\text { NorESM1- } \\
\text { M }\end{array}$} & $\begin{array}{c}127 . \\
2\end{array}$ & $\begin{array}{c}81 . \\
5\end{array}$ & 161 & $\begin{array}{c}77 . \\
5\end{array}$ & $\begin{array}{c}79 . \\
6\end{array}$ & 133 & $\begin{array}{c}125 . \\
8\end{array}$ & $\begin{array}{c}81 . \\
4\end{array}$ & $\begin{array}{c}163 . \\
3\end{array}$ & $\begin{array}{c}72 . \\
9\end{array}$ & 77 & $\begin{array}{c}131 . \\
1\end{array}$ \\
\hline & \multicolumn{12}{|c|}{ Root-Mean-Square Difference (RMSD) } \\
\hline & \multicolumn{6}{|c|}{ Training (1976-2005) } & \multicolumn{6}{|c|}{ Testing (1951-1975) } \\
\hline & CNE & HR & $\mathbf{N E}$ & NW & PS & $\overline{W C}$ & CNE & HR & $\mathbf{N E}$ & NW & PS & $\mathbf{W C}$ \\
\hline IMD & 0 & 0 & 0 & 0 & 0 & 0 & 0 & 0 & 0 & 0 & 0 & 0 \\
\hline $\begin{array}{l}\text { BCC- } \\
\text { CSM1.1(m } \\
\text { ) }\end{array}$ & 19.4 & $\begin{array}{c}27 . \\
4\end{array}$ & 45.3 & $\begin{array}{c}15 . \\
8\end{array}$ & 14 & 16.8 & 20.8 & $\begin{array}{c}34 . \\
1\end{array}$ & 49.7 & $\begin{array}{c}16 . \\
9\end{array}$ & $\begin{array}{c}17 . \\
9\end{array}$ & 7.7 \\
\hline $\begin{array}{l}\text { HadGEM2- } \\
\text { AO }\end{array}$ & 46.7 & $\begin{array}{c}31 . \\
7\end{array}$ & 21 & $\begin{array}{c}23 . \\
2\end{array}$ & $\begin{array}{c}35 . \\
8\end{array}$ & 51 & 48 & $\begin{array}{c}35 . \\
5\end{array}$ & 27.6 & $\begin{array}{c}32 . \\
4\end{array}$ & $\begin{array}{c}27 . \\
5\end{array}$ & 44.5 \\
\hline $\begin{array}{l}\text { GFDL- } \\
\text { CM3 }\end{array}$ & 22.9 & $\begin{array}{c}36 . \\
4\end{array}$ & 27.7 & $\begin{array}{c}30 . \\
6\end{array}$ & $\begin{array}{c}23 . \\
1\end{array}$ & 25.1 & 23.5 & $\begin{array}{c}48 . \\
1\end{array}$ & 32.9 & $\begin{array}{c}30 . \\
8\end{array}$ & $\begin{array}{c}22 . \\
9\end{array}$ & 19.5 \\
\hline $\begin{array}{l}\text { GFDL- } \\
\text { ESM2G }\end{array}$ & 9.8 & $\begin{array}{c}29 . \\
2\end{array}$ & 38.8 & $\begin{array}{c}37 . \\
4\end{array}$ & $\begin{array}{c}21 . \\
3\end{array}$ & 25.2 & 22.4 & 31 & 31.5 & $\begin{array}{c}32 . \\
2\end{array}$ & $\begin{array}{c}18 . \\
8\end{array}$ & 16.8 \\
\hline $\begin{array}{l}\text { IPSL- } \\
\text { CM5A-LR }\end{array}$ & 83.8 & $\begin{array}{c}54 . \\
6\end{array}$ & 90.4 & $\begin{array}{c}63 . \\
1\end{array}$ & $\begin{array}{c}51 . \\
8\end{array}$ & 89.8 & 75.9 & $\begin{array}{c}56 . \\
5\end{array}$ & $\begin{array}{c}103 . \\
4\end{array}$ & $\begin{array}{c}54 . \\
6\end{array}$ & $\begin{array}{c}43 . \\
2\end{array}$ & 89.7 \\
\hline $\begin{array}{l}\text { IPSL- } \\
\text { CM5A-MR }\end{array}$ & 60.7 & $\begin{array}{c}41 . \\
8\end{array}$ & 59.8 & $\begin{array}{c}63 . \\
9\end{array}$ & $\begin{array}{c}41 . \\
5\end{array}$ & 82.9 & 64.4 & $\begin{array}{c}46 . \\
4\end{array}$ & 67.6 & $\begin{array}{c}51 . \\
9\end{array}$ & $\begin{array}{c}37 . \\
9\end{array}$ & 86.5 \\
\hline MIROC5 & 25.6 & $\begin{array}{c}18 . \\
1\end{array}$ & 63.4 & $\begin{array}{c}12 . \\
3\end{array}$ & $\begin{array}{c}21 . \\
7\end{array}$ & 16.6 & 33.8 & $\begin{array}{c}24 . \\
7\end{array}$ & 55.1 & $\begin{array}{c}29 . \\
2\end{array}$ & $\begin{array}{c}25 . \\
8\end{array}$ & 19.7 \\
\hline $\begin{array}{l}\text { MIROC- } \\
\text { ESM- } \\
\text { CHEM } \\
\end{array}$ & 41.2 & $\begin{array}{c}36 . \\
6\end{array}$ & 53.4 & $\begin{array}{c}14 . \\
6\end{array}$ & $\begin{array}{c}23 . \\
1\end{array}$ & 36.8 & 48.4 & $\begin{array}{c}31 . \\
2\end{array}$ & 55.6 & 21. & $\begin{array}{c}20 . \\
6\end{array}$ & 41.3 \\
\hline $\begin{array}{l}\text { NorESM1- } \\
\mathrm{M}\end{array}$ & 29.7 & $\begin{array}{c}20 . \\
9\end{array}$ & 24.5 & $\begin{array}{c}37 . \\
2\end{array}$ & $\begin{array}{c}28 . \\
3\end{array}$ & 42.5 & 22.7 & $\begin{array}{c}23 . \\
5\end{array}$ & 22.8 & $\begin{array}{c}16 . \\
4\end{array}$ & $\begin{array}{c}22 . \\
7\end{array}$ & 30.2 \\
\hline
\end{tabular}

Table 4 Identified set of models for MME preparation for different homogeneous region

\section{\begin{tabular}{|l|l}
\hline Region & Identified models \\
\hline
\end{tabular}}

This article is protected by copyright. All rights reserved. 


\begin{tabular}{|c|c|}
\hline Central Northeast & $\begin{array}{ll}\text { 1. } & \text { BCC-CSM1.1(m) } \\
\text { 2. } & \text { GFDL-CM3 } \\
\text { 3. } & \text { GFDL-ESM2G, } \\
\text { 4. } & \text { MIROC5 } \\
\text { 5. } & \text { NorESM1-M }\end{array}$ \\
\hline Hilly Regions & $\begin{array}{ll}\text { 1. } & \text { MIROC5 } \\
\text { 2. } & \text { NorESM1-M }\end{array}$ \\
\hline Northeast & $\begin{array}{ll}\text { 1. } & \text { HadGEM2-AO } \\
\text { 2. } & \text { GFDL-CM3 } \\
\text { 3. } & \text { GFDL-ESM2G } \\
\text { 4. } & \text { NorESM1-M }\end{array}$ \\
\hline Northwest & $\begin{array}{ll}\text { 1. } & \text { BCC-CSM1.1(m) } \\
\text { 2. } & \text { MIROC5 } \\
\text { 3. } & \text { MIROC-ESM-CHEM }\end{array}$ \\
\hline Peninsula India & $\begin{array}{ll}\text { 1. } & \text { BCC-CSM1.1(m) } \\
\text { 2. } & \text { GFDL-CM3 } \\
\text { 3. } & \text { GFDL-ESM2G } \\
\text { 4. } & \text { MIROC5 }\end{array}$ \\
\hline West Central & $\begin{array}{ll}\text { 1. } & \text { BCC-CSM1.1(m) } \\
\text { 2. } & \text { GFDL-CM3 } \\
\text { 3. } & \text { GFDL-ESM2G } \\
\text { 4. } & \text { MIROC5 }\end{array}$ \\
\hline
\end{tabular}

Table 5 Trend analysis statistics for areal spread of drought

\begin{tabular}{|l|c|c|c|c|c|}
\hline & \multicolumn{2}{|c|}{ Moderate droughts } & \multicolumn{2}{c|}{ Above moderate droughts } \\
\hline & Z-score & $\begin{array}{c}\text { Theil-Sen's } \\
\text { Slope }\end{array}$ & Z-score & $\begin{array}{c}\text { Theil-Sen's } \\
\text { Slope }\end{array}$ \\
\hline \multicolumn{2}{|c|}{ MME historical (1976-2005) } & -0.64 & -0.13 & -1.00 & -0.40 \\
\hline \multicolumn{2}{|c|}{ Near-future (2010-2039) } & -0.75 & -0.11 & 1.32 & 0.30 \\
\hline
\end{tabular}

This article is protected by copyright. All rights reserved. 


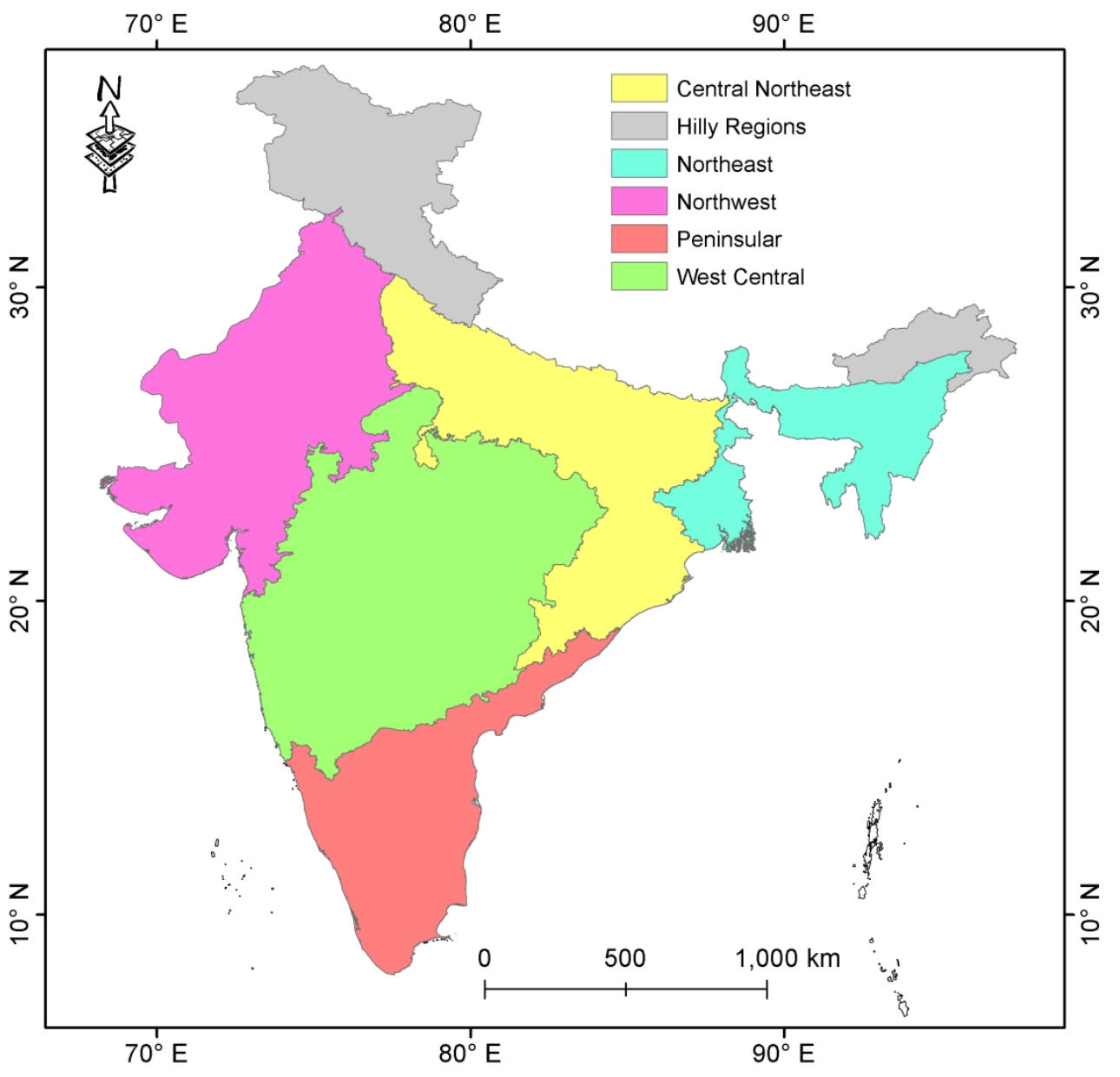

Figure 1

$215 \times 207 \mathrm{~mm}(300 \times 300$ DPI $)$

This article is protected by copyright. All rights reserved. 


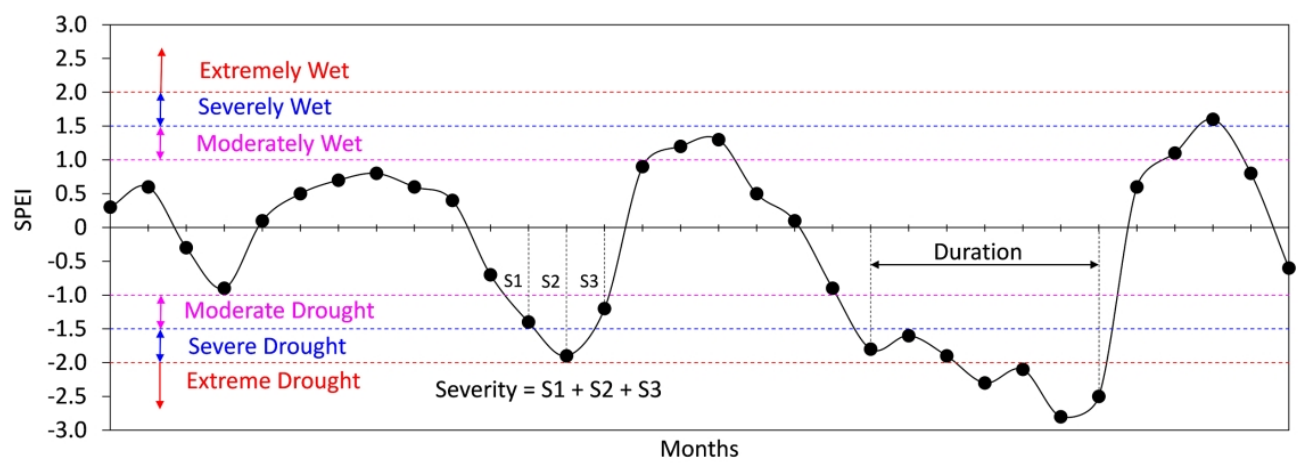

Figure 2

$661 \times 242 \mathrm{~mm}(96 \times 96 \mathrm{DPI})$

This article is protected by copyright. All rights reserved. 

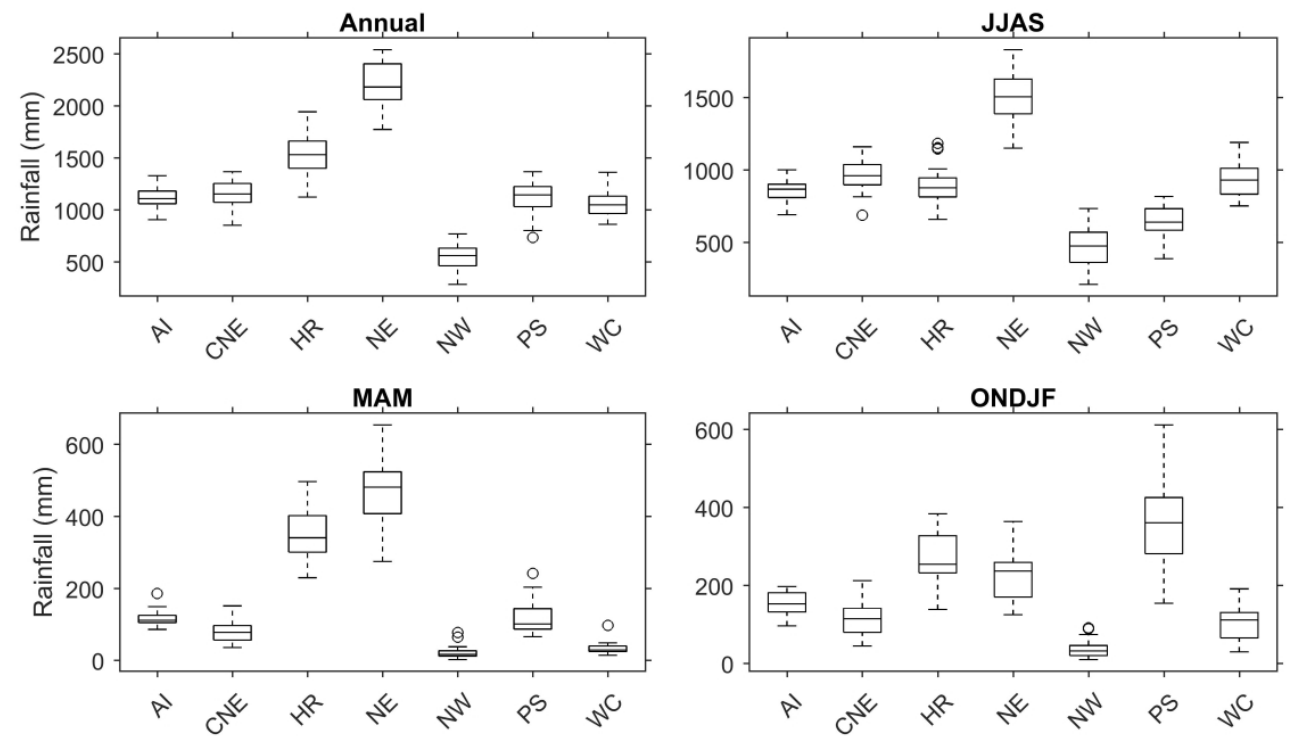

Figure 3

$1481 \times 846 \mathrm{~mm}(72 \times 72 \mathrm{DPI})$

This article is protected by copyright. All rights reserved. 

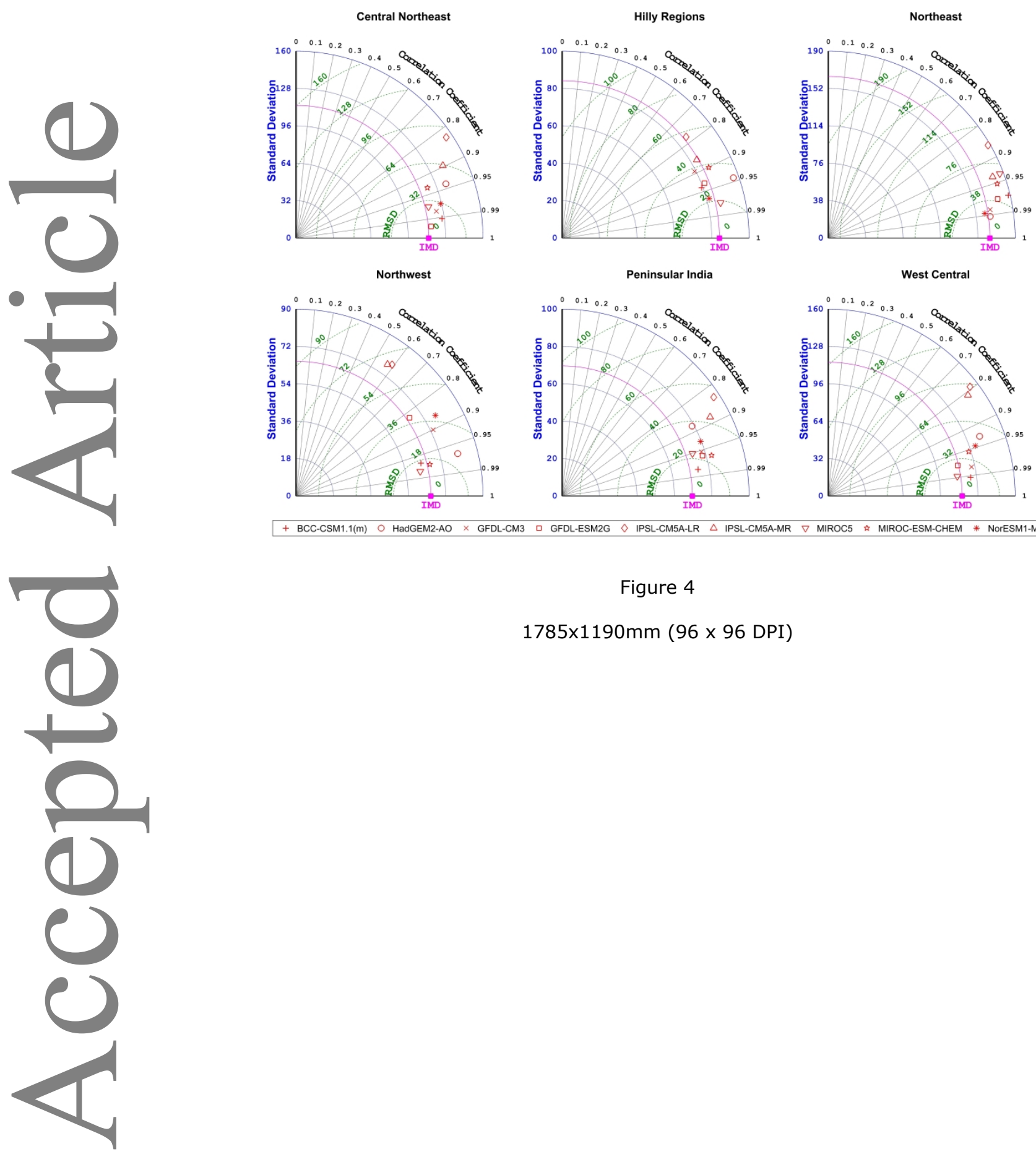

Figure 4

$1785 \times 1190 \mathrm{~mm}(96 \times 96 \mathrm{DPI})$

This article is protected by copyright. All rights reserved. 

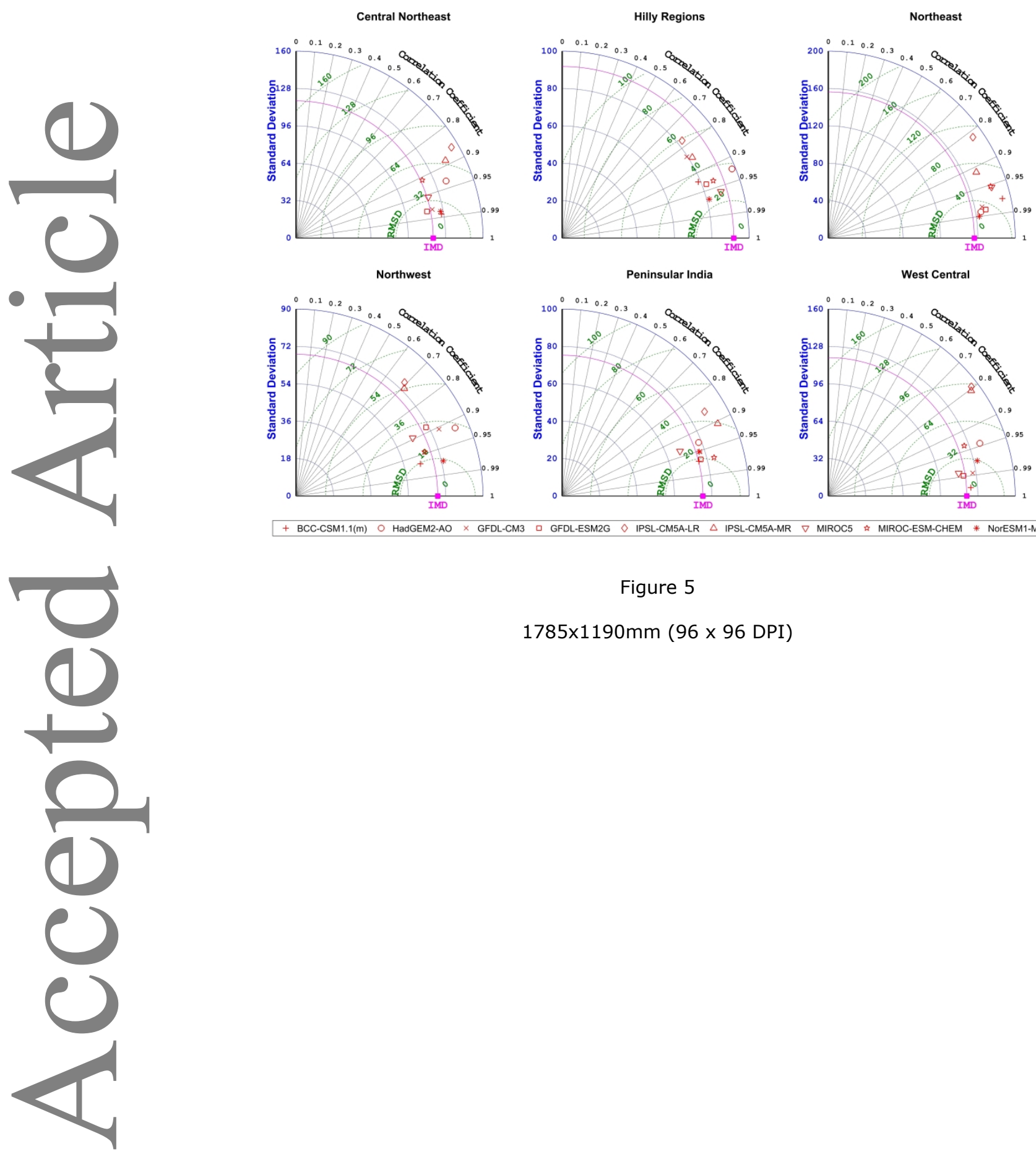

Figure 5

$1785 \times 1190 \mathrm{~mm}(96 \times 96 \mathrm{DPI})$

This article is protected by copyright. All rights reserved. 

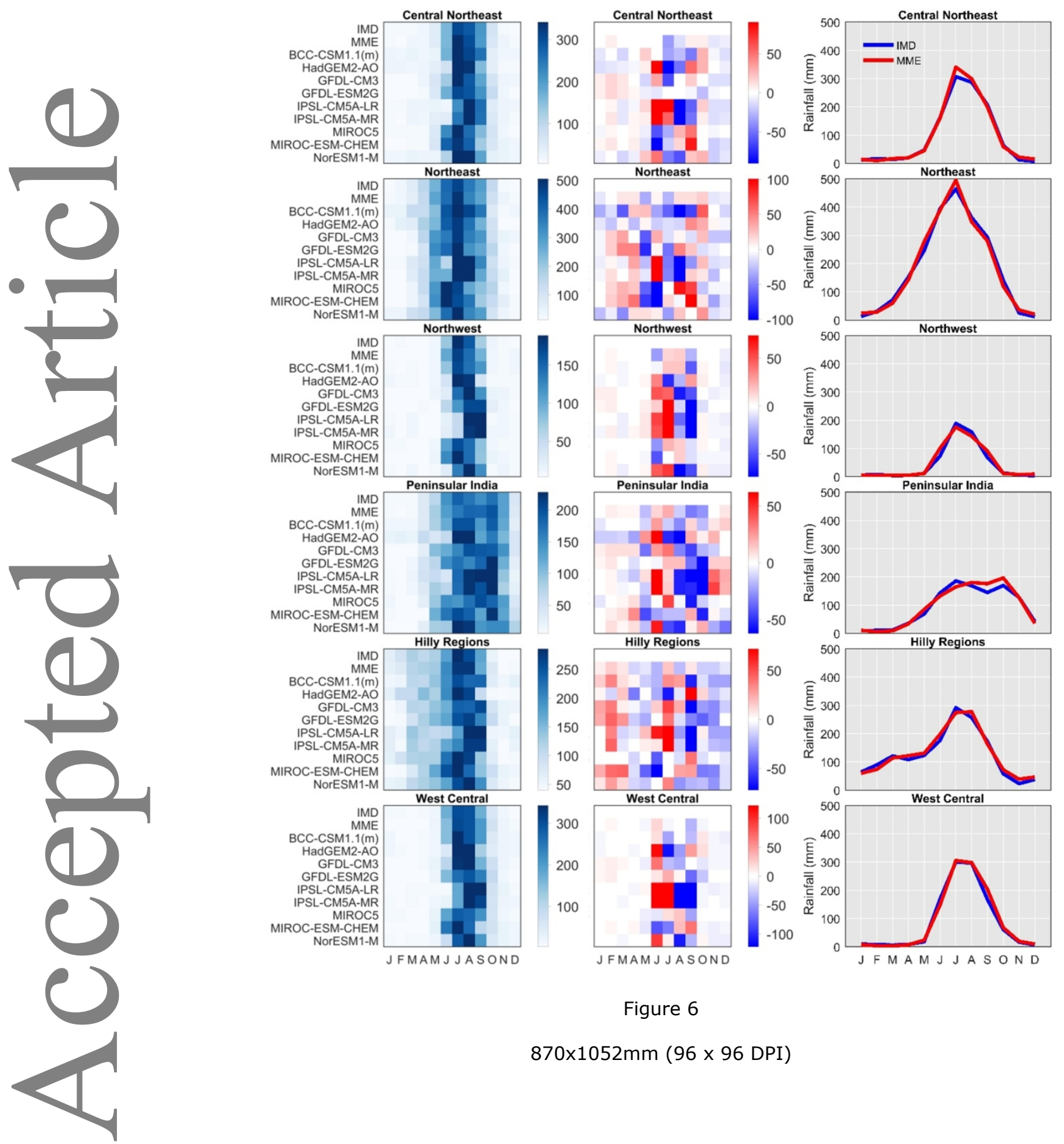

Figure 6

$870 \times 1052 \mathrm{~mm}(96 \times 96 \mathrm{DPI})$

This article is protected by copyright. All rights reserved. 

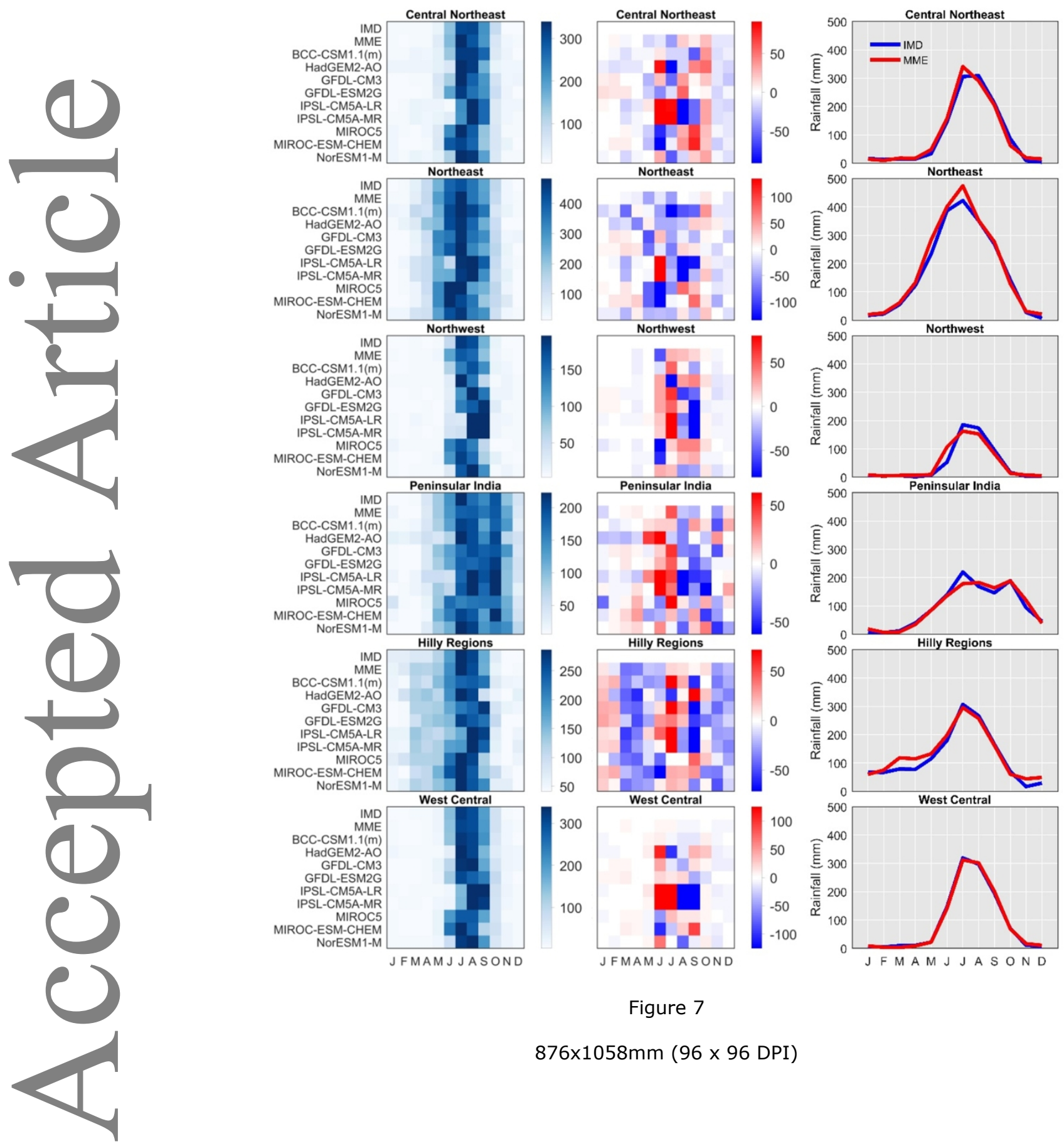

Figure 7

$876 \times 1058 \mathrm{~mm}(96 \times 96 \mathrm{DPI})$ 

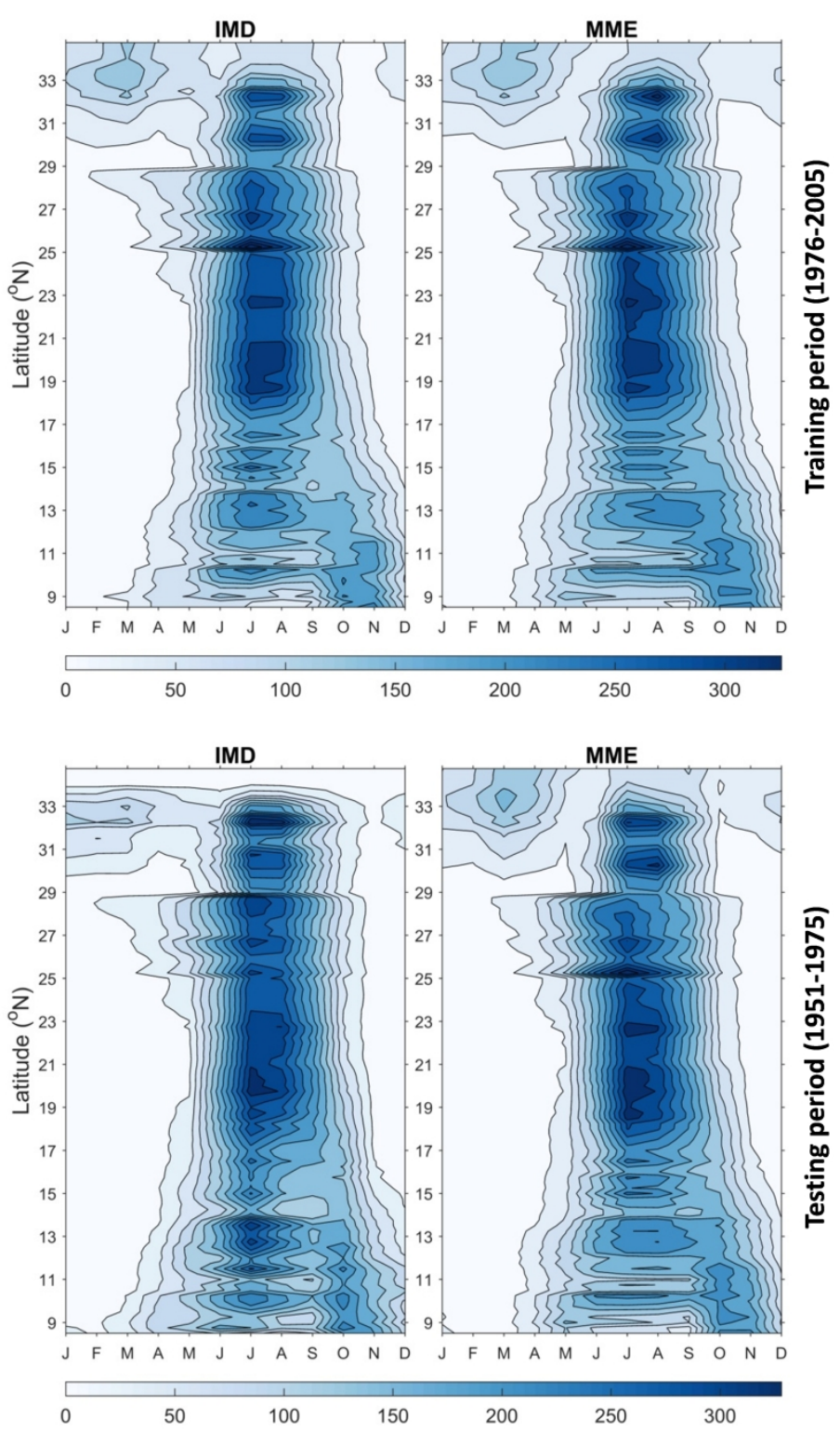

Figure 8

$789 \times 1323 \mathrm{~mm}(96 \times 96 \mathrm{DPI})$

This article is protected by copyright. All rights reserved. 

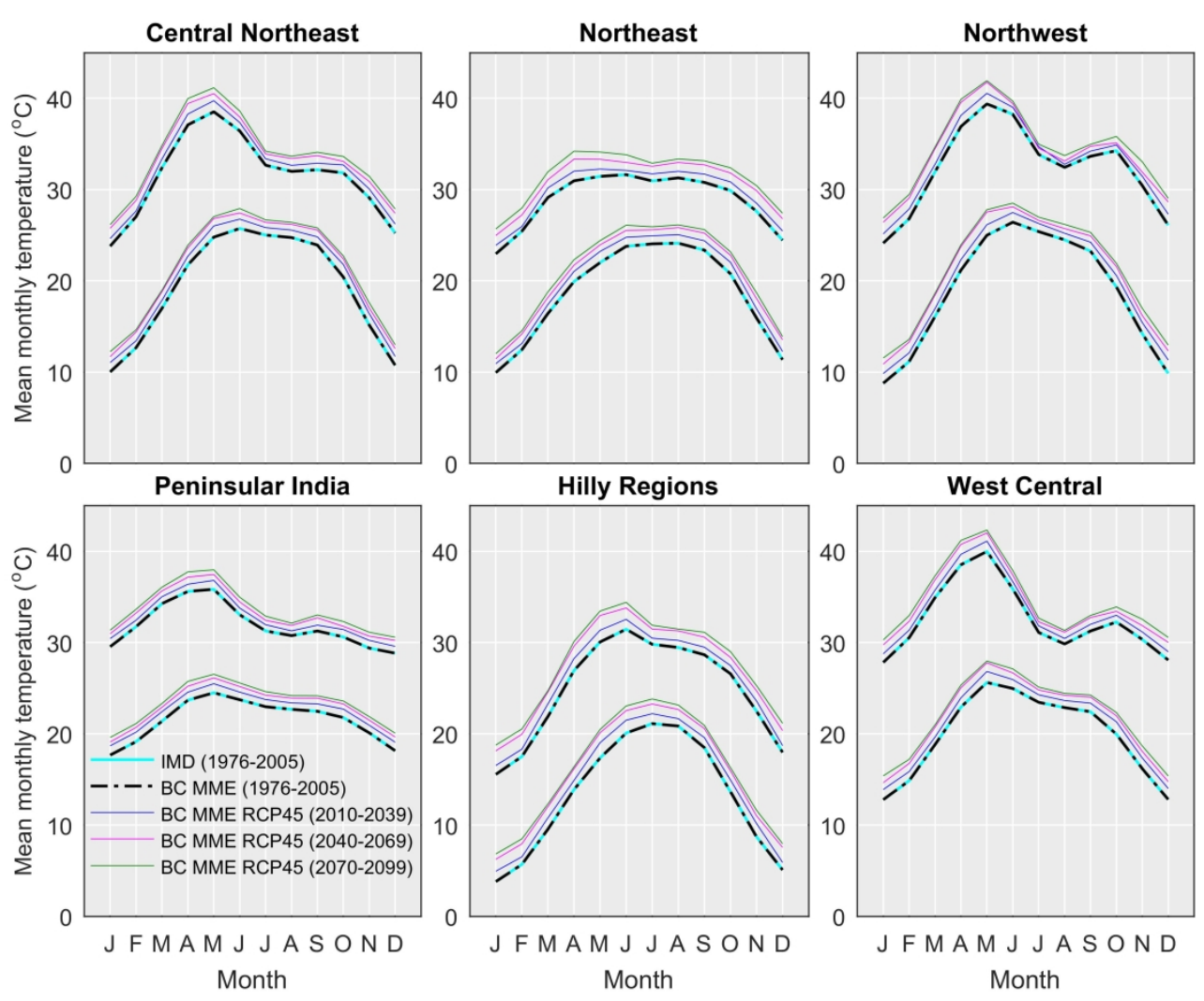

Figure 9

$1270 \times 1058 \mathrm{~mm}(72 \times 72 \mathrm{DPI})$

This article is protected by copyright. All rights reserved. 

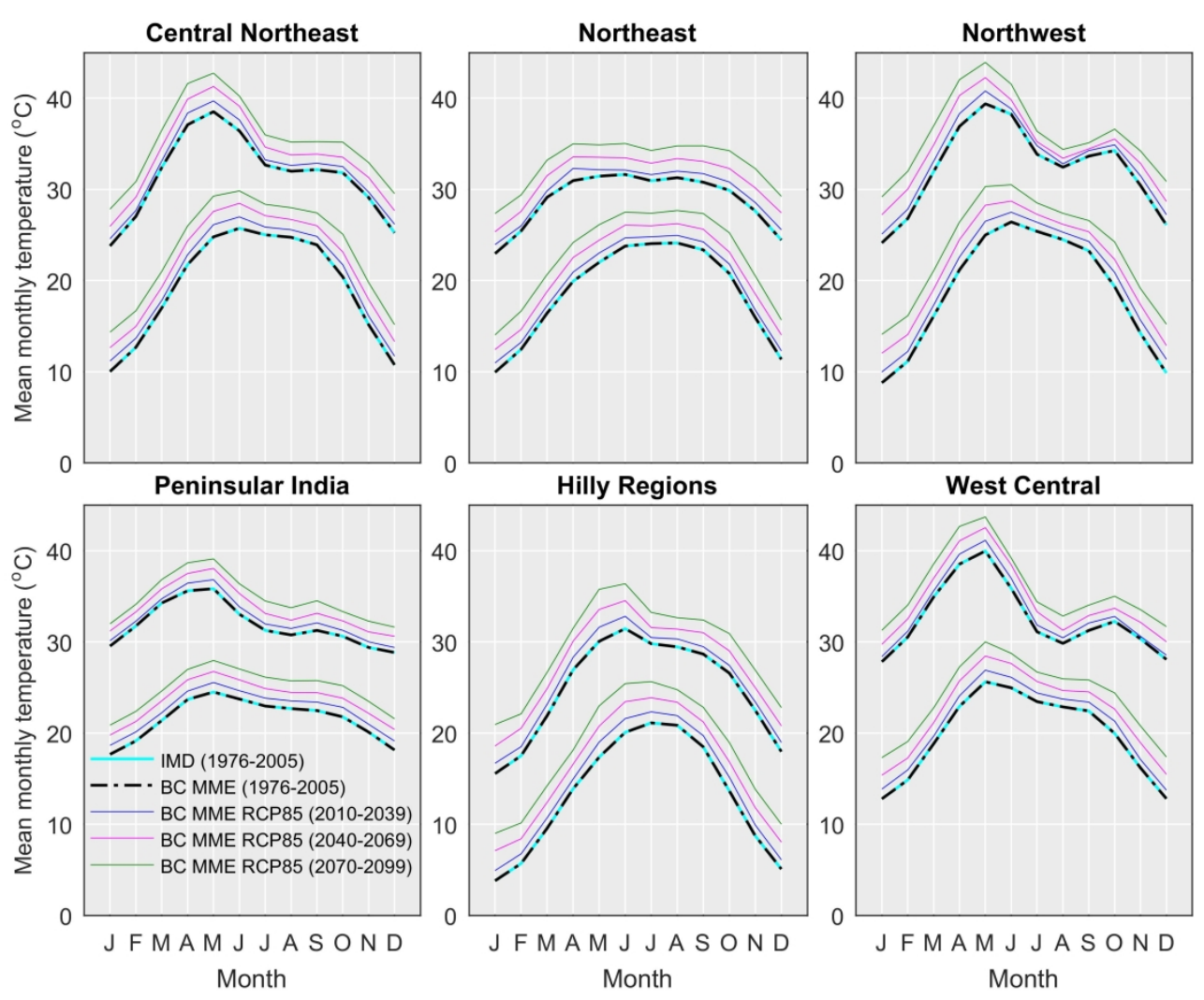

Figure 10

$1270 \times 1058 \mathrm{~mm}(72 \times 72$ DPI $)$

This article is protected by copyright. All rights reserved. 

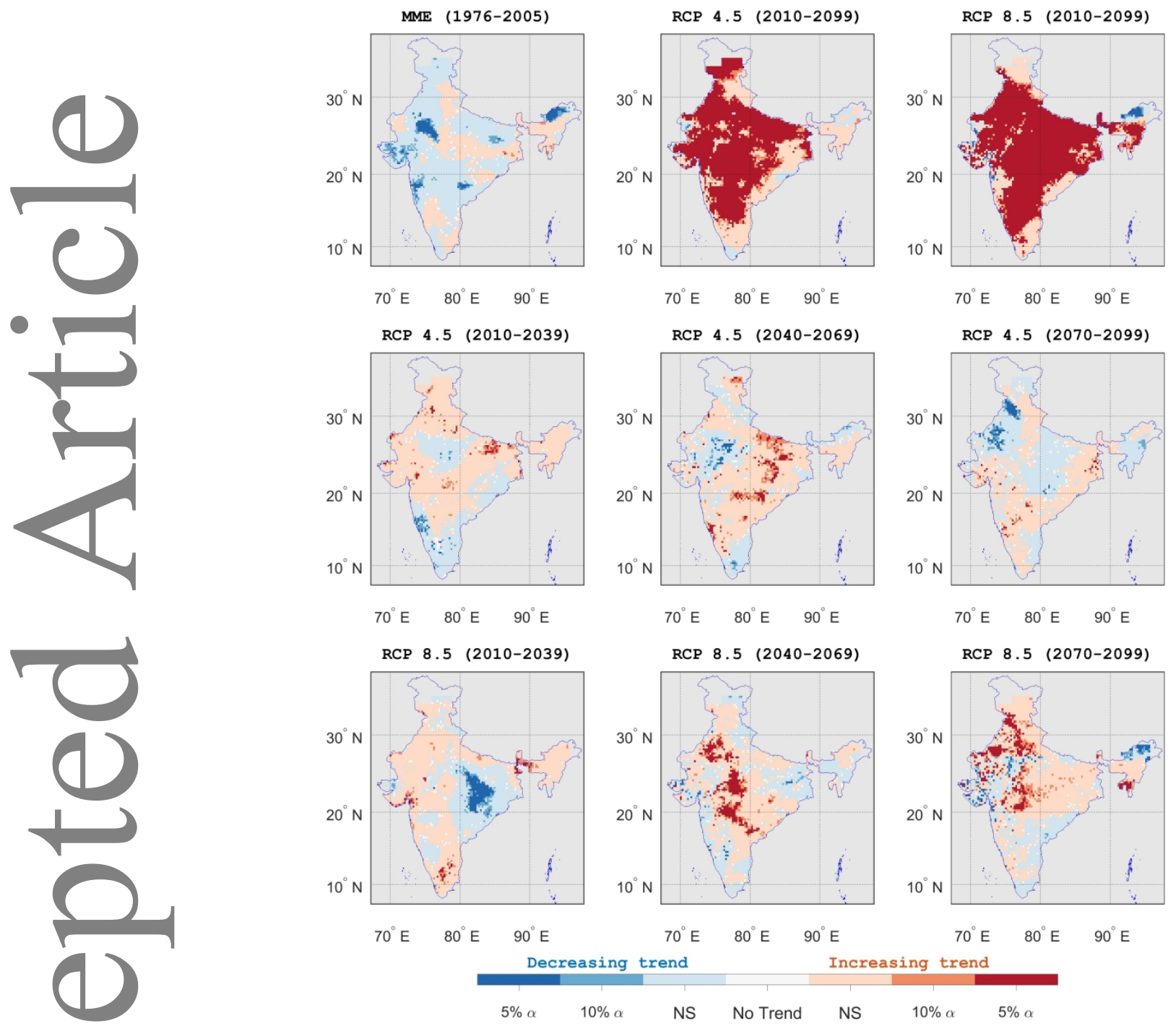

Figure 11

$1111 \times 1270 \mathrm{~mm}(72 \times 72 \mathrm{DPI})$

This article is protected by copyright. All rights reserved. 

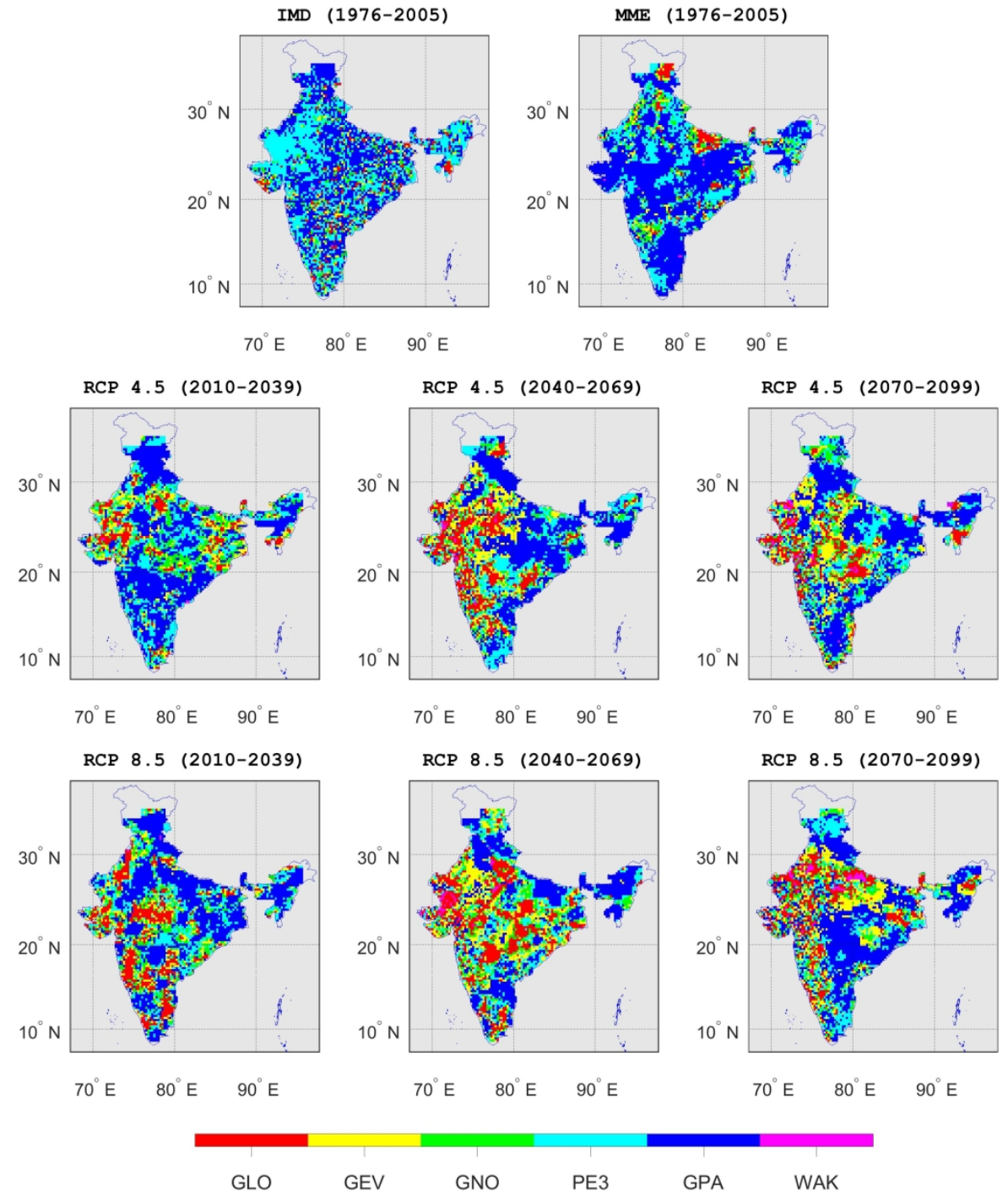

Figure 12

$1111 \times 1270 \mathrm{~mm}(72 \times 72$ DPI $)$

This article is protected by copyright. All rights reserved. 

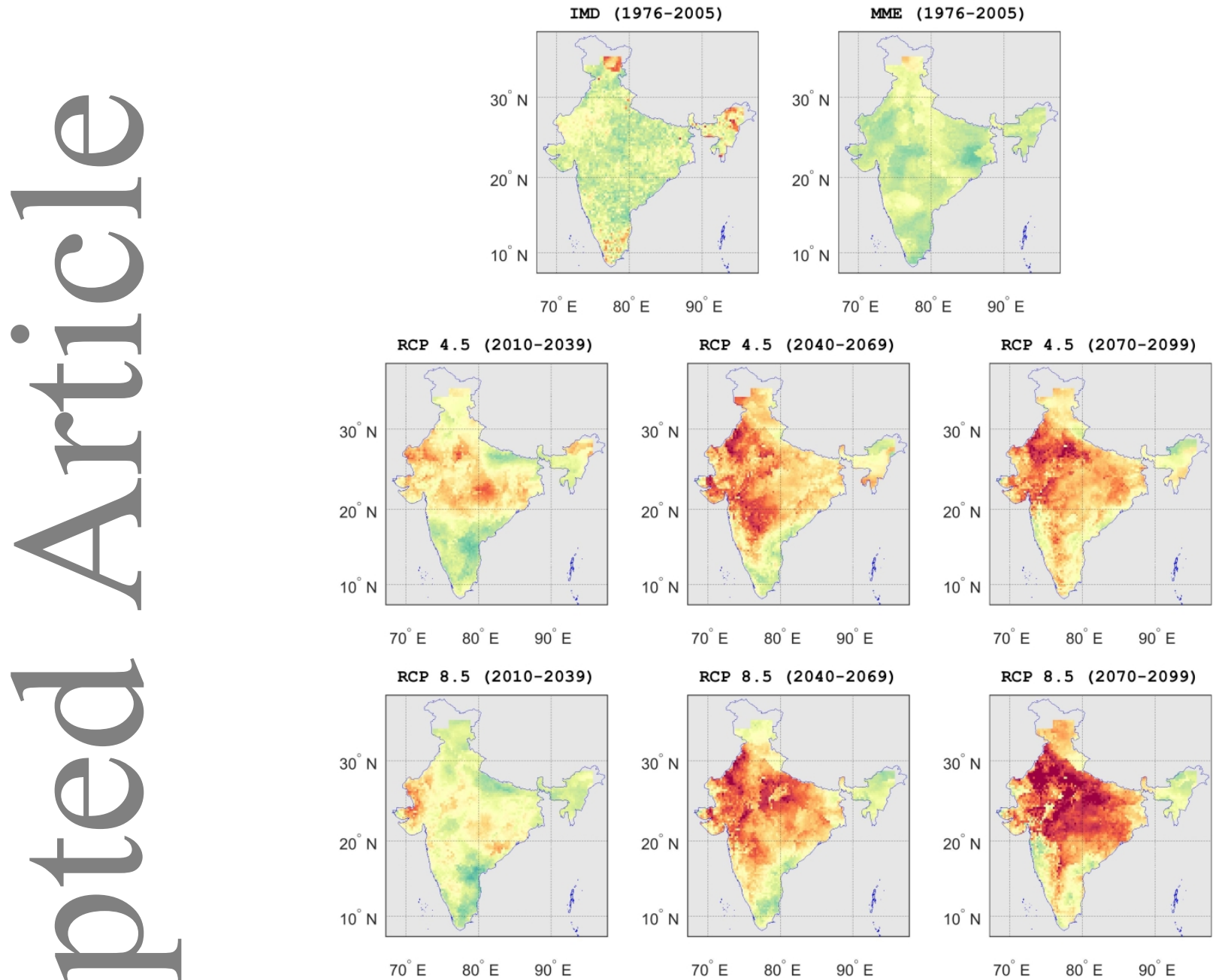

Figure 13

$1111 \times 1270 \mathrm{~mm}(72 \times 72 \mathrm{DPI})$

This article is protected by copyright. All rights reserved. 

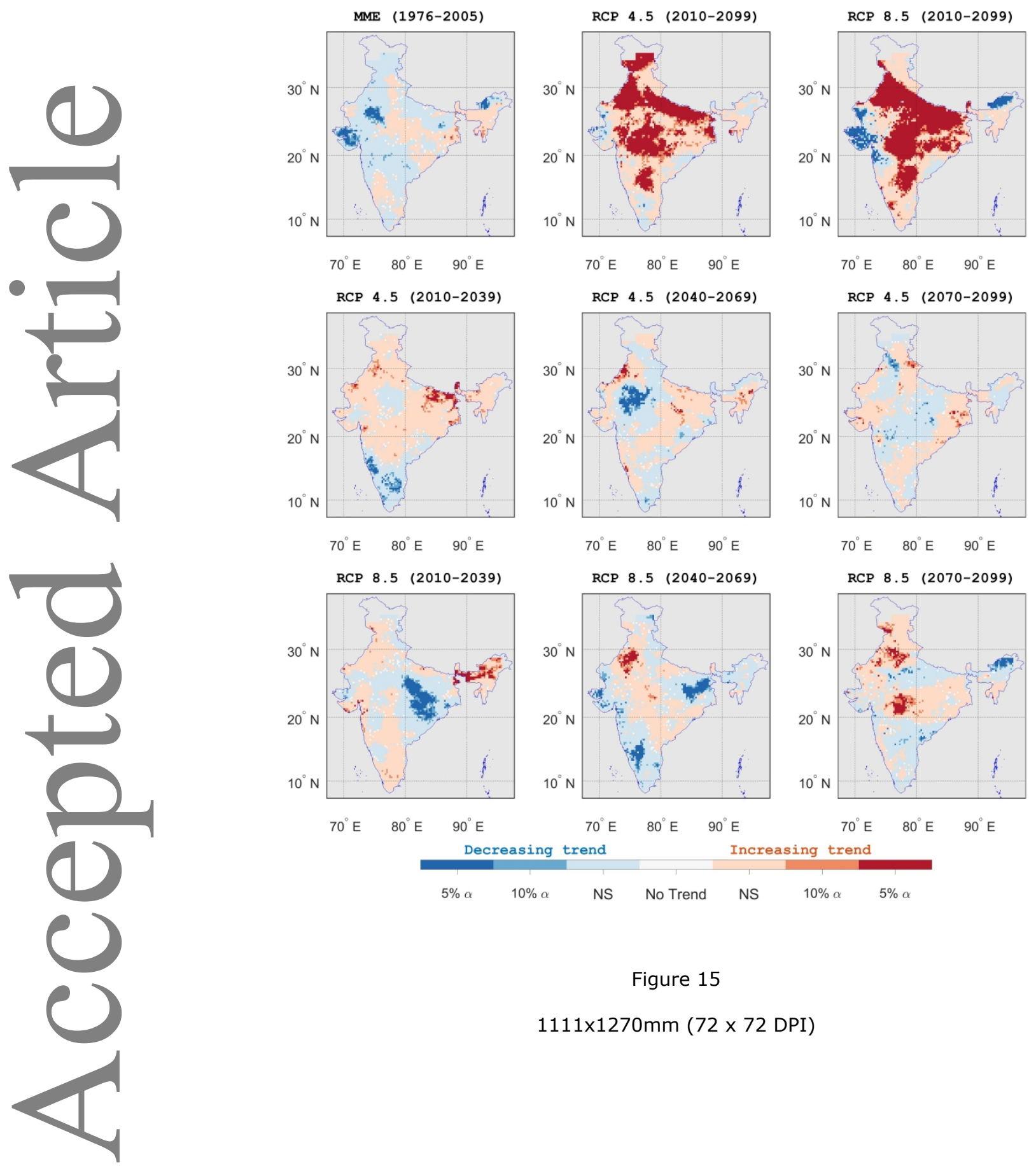

Figure 15

$1111 \times 1270 \mathrm{~mm}(72 \times 72 \mathrm{DPI})$

This article is protected by copyright. All rights reserved. 

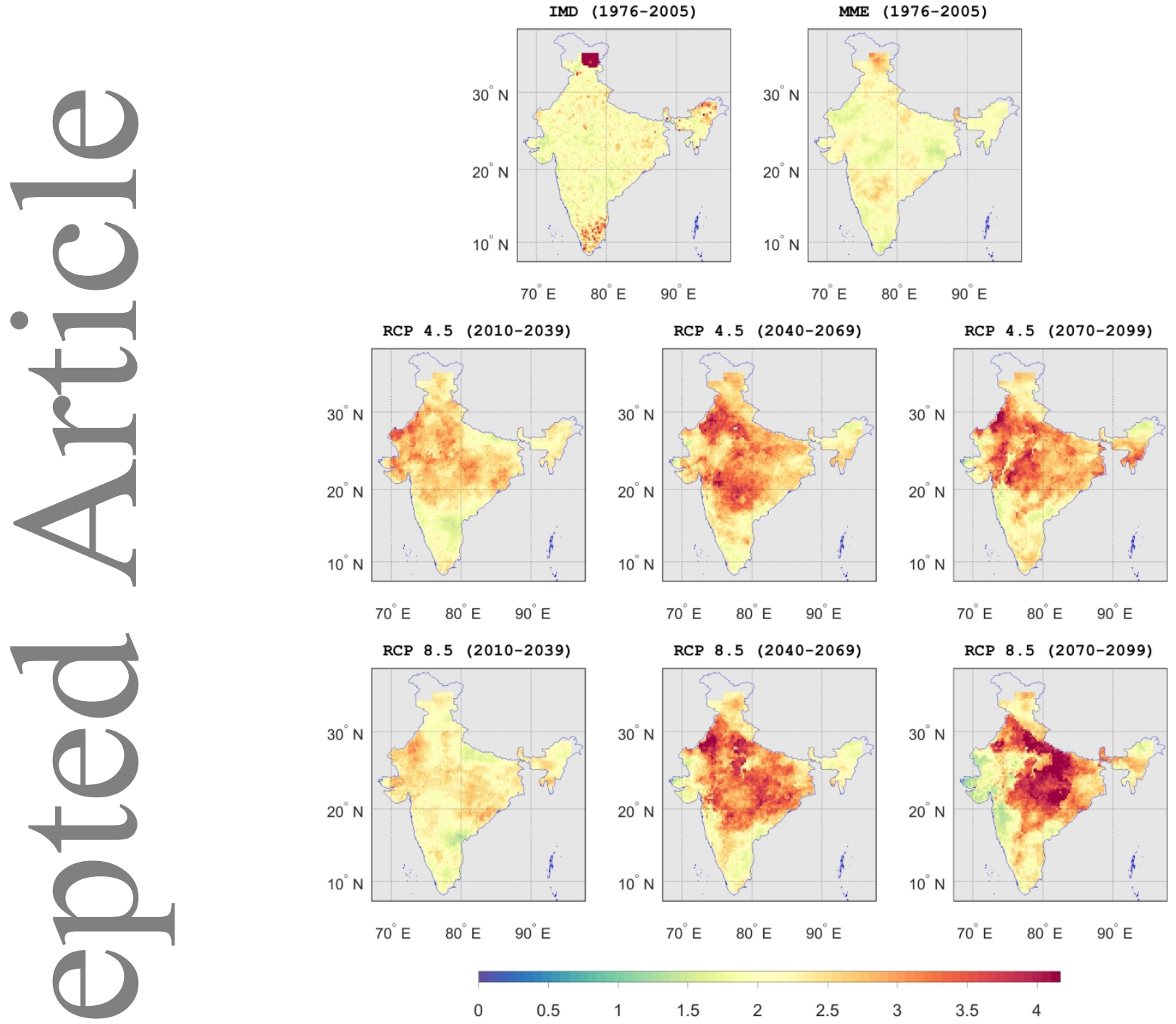

Figure 16

$1111 \times 1270 \mathrm{~mm}(72 \times 72$ DPI $)$

This article is protected by copyright. All rights reserved. 

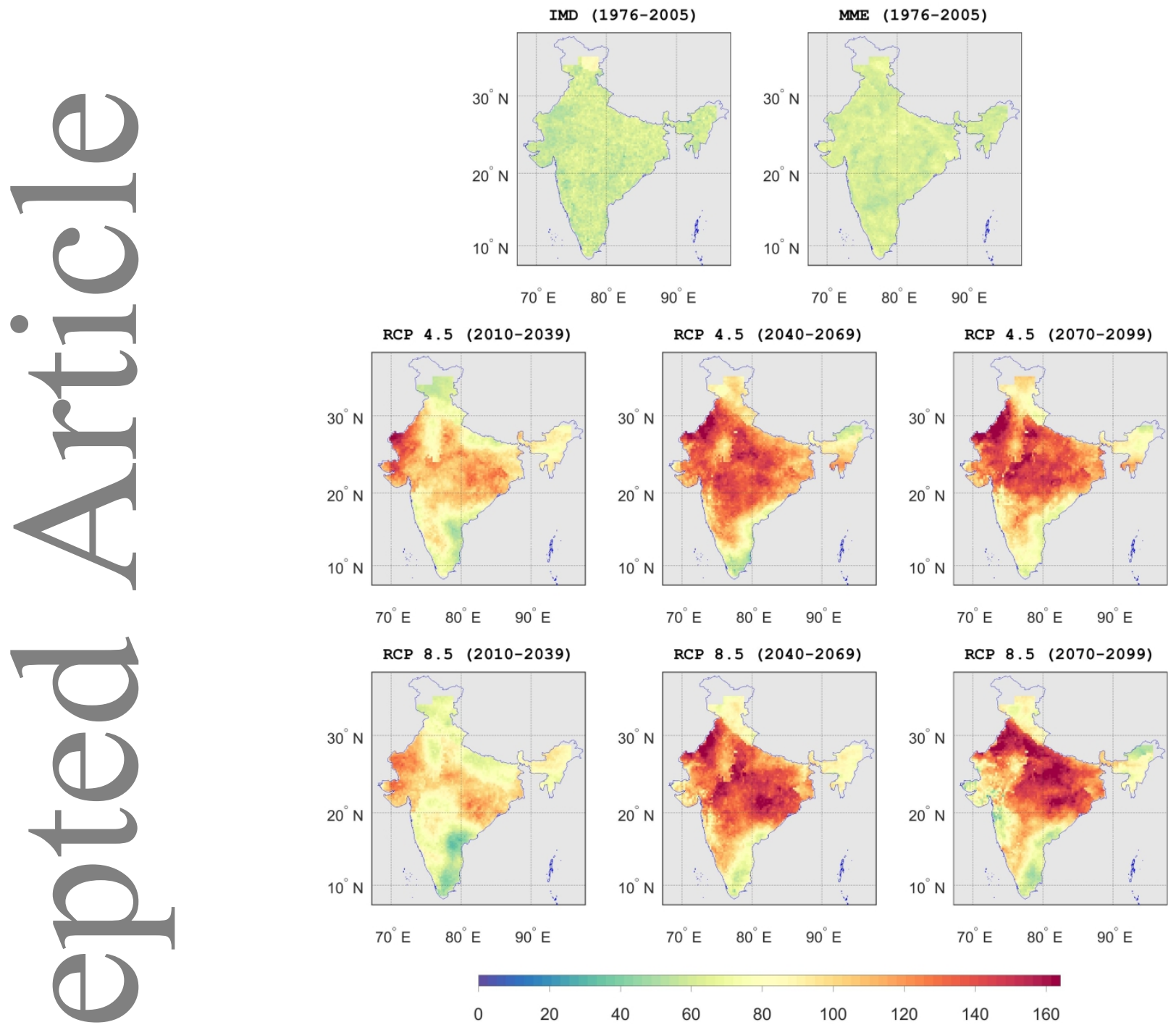

Figure 17

$1111 \times 1270 \mathrm{~mm}(72 \times 72 \mathrm{DPI})$

This article is protected by copyright. All rights reserved. 